Article

\title{
Boosting Drug Discovery for Parkinson's: Enhancement of the Delivery of a Monoamine Oxidase-B Inhibitor by Brain-Targeted PEGylated Polycaprolactone-Based Nanoparticles
}

\author{
Miguel Pinto ${ }^{1,+}$, Carlos Fernandes ${ }^{1,+}{ }^{\oplus}$, Eva Martins ${ }^{2}{ }^{\circ}$, Renata Silva $^{2}\left(\mathbb{D}\right.$, Sofia Benfeito ${ }^{1}$, \\ Fernando Cagide $\left.{ }^{1}{ }^{(}\right)$, Ricardo F. Mendes ${ }^{3}{ }^{\circledR}$, Filipe A. Almeida Paz ${ }^{3}{ }^{\circledR}$, Jorge Garrido ${ }^{4}$, \\ Fernando Remião ${ }^{2}(\mathbb{D}$ and Fernanda Borges $1, * \mathbb{1}$ \\ 1 CIQUP, Departmento de Química e Bioquímica, Centro de Investigação em Química, Faculdade de Ciências, \\ Universidade do Porto, 4169-007 Porto, Portugal \\ 2 UCIBIO-REQUIMTE, Laboratório de Toxicologia, Departamento de Ciências Biológicas, \\ Faculdade de Farmácia, Universidade do Porto, 4050-313 Porto, Portugal \\ 3 Departamento de Química, CICECO-Instituto de Materiais de Aveiro, Universidade de Aveiro, \\ 3810-193 Aveiro, Portugal \\ 4 Departamento de Engenharia Química, Instituto Superior de Engenharia do Porto (ISEP), \\ Instituto Politécnico do Porto, 4200-072 Porto, Portugal \\ * Correspondence: fborges@fc.up.pt \\ + These authors contributed equally to this work.
}

Received: 15 May 2019; Accepted: 9 July 2019; Published: 12 July 2019

\begin{abstract}
The current pharmacological treatments for Parkinson's disease only offer symptomatic relief to the patients and are based on the administration of levodopa and catechol-O-methyltransferase or monoamine oxidase-B inhibitors (IMAO-B). Since the majority of drug candidates fail in preand clinical trials, due largely to bioavailability pitfalls, the use of polymeric nanoparticles (NPs) as drug delivery systems has been reported as an interesting tool to increase the stealth capacity of drugs or help drug candidates to surpass biological barriers, among other benefits. Thus, a novel potent, selective, and reversible IMAO-B (chromone C27, $\mathrm{IC}_{50}=670 \pm 130 \mathrm{pM}$ ) was encapsulated in poly(caprolactone) (PCL) NPs by a nanoprecipitation process. The resulting C27-loaded PEGylated PCL NPs $(\sim 213 \mathrm{~nm})$ showed high stability and no cytotoxic effects in neuronal (SH-SY5Y), epithelial (Caco-2), and endothelial ( $h$ CMEC/D3) cells. An accumulation of PEGylated PCL NPs in the cytoplasm of SH-SY5Y and $h \mathrm{CMEC} / \mathrm{D} 3$ cells was also observed, and their permeation across Caco-2 and $h \mathrm{CMEC} / \mathrm{D} 3$ cell monolayers, used as in vitro models of the human intestine and blood-brain barrier, respectively, was demonstrated. PEGylated PCL NPs delivered C27 at concentrations higher than the MAO-B $\mathrm{IC}_{50}$ value, which provides evidence of their relevance to solving the drug discovery pitfalls.
\end{abstract}

Keywords: Parkinson disease; chromone; monoamine oxidase B inhibitor; PEGylated nanoparticles; intestinal and brain permeability

\section{Introduction}

Parkinson's disease (PD) is a multifactorial disorder characterized by the progressive degeneration of the structure and well-function of the central nervous system (CNS), leading to a depletion of dopaminergic neurons in the substantia nigra [1]. The decrease of the neurotransmitter dopamine in neuron cleft is associated with movement control and cognitive losses, which appear as a form 
of tremors, memory loss, and inconsistent speech. Nowadays, PD is the second most prevalent neurodegenerative disorder, affecting 1-2\% of the world's population above 65 years of age, increasing to approximately $4 \%$ in individuals above 85 years of age [2].

Despite how clinical trials for PD have long relied on observing whether a therapy improves the symptomatology of patients, the studies performed so far were not able to reveal information about how the treatment affects the progressive neurodegeneration process. The current pharmacological treatments only offer symptomatic relief to the patients [3], and are based on the administration of levodopa and catechol-O-methyltransferase or monoamine oxidase B inhibitors (IMAO-B) [4].

Monoamine oxidase- $\mathrm{B}$ (MAO-B) is one of the isoforms of monoamine oxidases involved in the metabolization of dopamine in neuronal tissues, whose expression increases about 4-fold with aging. Therefore, IMAO-Bs are used to decrease the turnover rate of striatal dopamine in early PD, or as an adjunctive therapy in patients treated with levodopa that are experiencing motor complications [3]. However, until now, no IMAO-B developed so far has been able to modify or revert the progression of PD [5].

As a result, in recent years, an intensive search focused on the discovery of novel IMAO-B has been carried out and, in line, chromone has emerged as a validated scaffold (Figure 1) for the development of novel MAO inhibitors [6,7]. In fact, a chromone-based compound (Figure 1, C27) has been reported as a potent, selective, and reversible IMAO-B $\left(\mathrm{IC}_{50}=670 \pm 130 \mathrm{pM}\right)$ [5]. This $\mathrm{IC}_{50}$ value is one order of magnitude lower than the reference inhibitors $\left((\mathrm{R})-(-)\right.$-deprenyl $\left(\mathrm{IC}_{50}=16.73 \pm 1.48 \mathrm{nM}\right)$, rasagiline $\left(\mathrm{IC}_{50}=49.66 \pm 2.26 \mathrm{nM}\right)$ and safinamide $\left(\mathrm{IC}_{50}=23.07 \pm 2.07 \mathrm{nM}\right)$ [8]. Despite C27's remarkable outline, several setbacks, mainly related to poor water solubility and bioavailability, have hampered the progress toward in vivo preclinical studies.<smiles>O=c1ccoc2ccccc12</smiles>

Chromone scaffold<smiles>Cc1ccc(NC(=O)c2coc3ccccc3c2=O)cc1C</smiles>

Chromone $\mathbf{C 2 7}(\log \mathrm{P}=\mathbf{3 . 4 6})$<smiles>O=c1ccc2ccccc2o1</smiles><smiles>CCN(CC)c1ccc2cc(-c3nc4ccccc4s3)c(=O)oc2c1</smiles>

Coumarin scaffold

Coumarin $\mathrm{C6}(\log \mathrm{P}=\mathbf{5 . 4 6})$

Figure 1. Chemical structures of chromone C27 and coumarin C6. The values of $\log \mathrm{P}$ were obtained from the literature $[5,9]$.

To overcome the attrition rates of central nervous system (CNS) drug discovery and development programs, new precision nanomedicine approaches are being developed. The main goals of these new approaches are the increment of stability, solubility, and other tunable properties and therapeutic index, namely, by improving the targeted delivery across the blood-brain barrier (BBB), of neuroactive drugs and drug candidates.

Through the years, nanoparticles (NPs) based on biodegradable polymers have been used for controlled drug delivery and to improve the therapeutic performance of drugs. Recently, they have been also used to solve shortcomings related to the solubility, stability, and bioavailability of drug candidates and other bioactive molecules $[10,11]$. Among the various biodegradable polymers approved by 
the US Food and Drug Administration, poly(lactide) (PLA), poly(D,L-lactide-co-glycolide) (PLGA), and poly(caprolactone) (PCL) are the most reported in the literature [12]. In particular, PCL is described as a non-toxic semi-crystalline hydrophobic polyester, miscible with a variety of polymers, with a high toughness and biocompatibility, since, in physiological conditions, it degrades slower than other biodegradable polyesters [13]. The surface of NPs can be coated with PEGylated surfactants, such as polysorbate 80 (Tween ${ }^{\circledR} 80$, T80) or poloxamers [8,14], to increase the permeability of NPs into the brain [15]. This process is described to be related to an improvement of the blood circulation time and to the stealth nature of PEG-coated NPs [16]. The PEGylated moiety shields the surface from aggregation, opsonization, and phagocytosis, ensuring the NPs remain undetected by the reticuloendothelial system and increasing their blood circulation half-life [17]. In line with this, Wilson et al. used NPs coated with T80 to deliver rivastigmine and tacrine in rat brains [18,19]. PCL-T80 NPs were also reported to be internalized into glioma C6 cells, with a higher cellular uptake than the PCL NPs, and were able to successfully deliver a nerve growth factor into outbred C57BL/6 mice brain [20,21]. Furthermore, Wang et al. proved that PCL-T80 NPs were capable of delivering paclitaxel in the brains of male Sprague-Dawley rats after intravenous injection [22].

A handful of studies have addressed the use of PEGylated NPs to tackle drug discovery and development problems in the field of neurodegenerative diseases [23]. Even though rasagiline and selegiline (IMAO-B used in therapy) were effectively encapsulated in polymeric NPs $[3,24]$, a gap still exists on the use of nanotechnology to solve site-targeted and absorption, distribution, metabolism, excretion, and toxicity (ADMET) problems along the pre-clinical phase. Herein, the IMAO-B chromone C27 was encapsulated into PCL NPs coated with T80 and a nanoformulation with suitable morphological and physicochemical properties was obtained after an optimization process. The release profile of $\mathrm{C} 27$ from PEGylated PCL NPs was evaluated, as well as the unloaded and loaded NPs cytotoxicity outline in human differentiated neuroblastoma (SH-SY5Y), epithelial colorectal adenocarcinoma (Caco-2), and endothelial brain ( $h$ CMEC/D3) cells. Moreover, cellular uptake (in SH-SY5Y and $h$ CMEC/D3 cells) and permeability studies (in Caco-2 and $h \mathrm{CMEC} / \mathrm{D} 3$ cells) were performed. For the cellular uptake, intracellular localization, and permeability studies, PEGylated PCL NPs containing a fluorescent coumarin-based probe (coumarin-6 dye, Figure 1) were also prepared.

\section{Materials and Methods}

\subsection{Materials and Reagents}

Polycaprolactone (PCL, $M_{n} \approx 10,000 \mathrm{Da}$, determined by gel permeation chromatography) and polysorbate 80 (T80) were purchased from Sigma-Aldrich (Sintra, Portugal) and used without further purification. The reagents and solutions used for cell-based assays were described in [8] and are detailed in the Supplementary Materials. EndoGRO Media was acquired from Merck (Cambridge, MA, USA) and rat tail collagen type I (low viscosity) was purchased from Cultrex. Other reagents were obtained from Sigma-Aldrich (Sintra, Portugal). The water used was Milli-Q filtered (Millipore, Burlington, MA, USA).

\subsection{Synthesis of $N-\left(3^{\prime}, 4^{\prime}\right.$-Dimethylphenyl)-4-oxo-4H-chromene-3-carboxamide (C27)}

The synthesis of $\mathrm{N}$-( $3^{\prime}, 4^{\prime}$-dimethylphenyl)-4-oxo-4H-chromene-3-carboxamide (C27) was previously reported [5]. The structural characterization and purity were ascertained by nuclear magnetic resonance $\left({ }^{1} \mathrm{H}\right.$ NMR,${ }^{13} \mathrm{C}$ NMR and DEPT) (data available in the Supplementary Materials).

\subsection{Preparation of PEGylated PCL-Based NPS}

The encapsulation of chromone C27 in PEGylated PCL-based NPs was performed using the nanoprecipitation method [8]. The nanoformulation was prepared by dissolving PCL and C27 $(2.5,5$ or $10 \%$ of PCL weight) in acetone and adding it dropwise to Milli-Q water containing $0.2 \%$ T80 under vigorous magnetic stirring. The resulting suspension was left under stirring for $1 \mathrm{~h}$ at 
room temperature. Acetone was then fully eliminated by evaporation under reduced pressure at room temperature. C27 loaded NPs were purified by ultrafiltration (10 min, 3000× g, Amicon Ultra $100 \mathrm{kDa}$ MWCO, Millipore) and stored at $4{ }^{\circ} \mathrm{C}$ until use. The unloaded NPs were similarly prepared, as described above.

The encapsulation of coumarin-6 (C6) in PCL NPs was performed in a similar manner to that described above ( $1 \% w / w$ of PCL).

For simplicity, from this point onwards PCL nanoformulations containing C27 and C6 will be labelled PCL@C27 NPs and PCL@C6 NPs, respectively. Unloaded NPs will be referred to as PCL NPs.

\subsection{Encapsulation and Drug Loading Efficiency}

The quantification of chromone C27 was performed using a Shimadzu UV-Vis spectrophotometer (UV-1700 PharmaSpec, Kyoto, Japan). The C27 UV/Vis spectra were obtained using a C27 solution $(50 \mu \mathrm{M})$ prepared in dimethyl sulfoxide (DMSO). The amount of C27 incorporated into the PCL@C27 NPs was determined directly after the complete dissolution of NPs in DMSO. The encapsulation efficiency (EE\%) was calculated as the ratio between the chromone content in the freeze-dried powder and the initial chromone amount used in the NPs preparation (Equation (1)) [25]. The drug loading capacity (DLC\%) was determined as the ratio between the amount of C27 encapsulated and the mass of NP powder (Equation (2)) [26].

$$
\begin{aligned}
\text { EE } \% & =\frac{\text { Amount of loaded C27 }}{\text { Amount of feeding C27 }} * 100 \% ; \\
\text { DLC } \% & =\frac{\text { Amount of loaded C } 27}{\text { Amount of PCL@C27 NPs }} * 100 \% .
\end{aligned}
$$

Briefly, $1 \mathrm{~mL}$ of nanosuspension was centrifuged $\left(15 \mathrm{~min}, 16,060 \times \mathrm{g}, 4^{\circ} \mathrm{C}\right)$ and washed three times with Milli-Q water. Then, the pellet was dried and dissolved in $1 \mathrm{~mL}$ of DMSO. Once completely dissolved, samples were quantified by UV-Vis spectrophotometry at $370 \mathrm{~nm}$. Experiments were performed in triplicate and under sink conditions.

The quantification of C6 encapsulated inside PCL NPs was performed using a fluorescent detection method [27]. After dissolving the pellet in $1 \mathrm{~mL}$ of DMSO, the resulting solution was measured using fluorescence radiation in a multi-well plate reader (excitation and emission wavelengths at 485 and $528 \mathrm{~nm}$, respectively). Experiments were performed in triplicate and under sink conditions.

The experiments performed in preformulation studies make it possible to conclude that PCL and T80 did not interfere in the analysis of both C27 and C6.

\subsection{Spectroscopic Analysis}

NMR spectra of free chromone C27, PCL@C27, and PCL NPs were acquired on a Bruker AMX 300 spectrometer operating at $400.13 \mathrm{MHz}$, at ambient temperature. Samples were dissolved in $\mathrm{CDCl}_{3}$ and analyzed with a final concentration of $30 \mathrm{mg} / \mathrm{mL}$. Chemical shifts are quoted in $\delta$ (ppm) values relative to tetramethylsilane (TMS) used as internal reference. Coupling constants $(J)$ are given in Hz.

\subsection{Particle Size, Zeta Potential, and Morphology Analysis}

The hydrodynamic particle size $\left(\mathrm{D}_{D L S}\right)$, polydispersity index (PdI), and zeta potential (z-potential) of all prepared NPs were analyzed by dynamic light scattering (DLS) and electrophoretic mobility, using a Zetasizer (Litesizer ${ }^{\mathrm{TM}} 500$, Anton Paar, Graz, Austria) equipped with a $4.0 \mathrm{~mW}$ internal laser. The resulting concentrated solutions of different NPs formulations were diluted $(10 \% v / v)$ in Milli-Q water, phosphate buffered saline solution PBS (1×), and Hank's balanced salt solution, with calcium and magnesium HBSS (+/+). Each value resulted from triplicate determinations. 
The morphology of the PCL and PCL@C27 NPs were analyzed by scanning electron microscopy (SEM) (JEOL JSM-6390, Tokyo, Japan). The experimental details were described in [8] and are detailed in the Supplementary Materials.

\subsection{Differential Scanning Calorimetry and Powder X-ray Diffraction}

Thermal analyses of chromone C27, PCL, and PCL@C27 NPs were performed in accordance with [8] and are detailed in the Supplementary Materials.

Powder X-ray diffraction (PXRD) was performed on an Empyrean PANalytical Diffractometer $\left(\mathrm{CuK}_{\alpha, 1,2} \mathrm{X}\right.$-radiation; $\left.\lambda_{1}=1.540598 \AA ; \lambda_{2}=1.544426 \AA\right)$, equipped with a PIXcel 1D detector and a flat-plate sample holder in a Bragg-Brentano para-focusing optics configuration (45 kV, $40 \mathrm{~mA})$ (Panalytical, Almelo, The Netherlands). Data were collected at ambient temperature. Intensity data was measured by the step-counting method (step $0.01^{\circ}$ ), in continuous mode, over the scan range $(2 \theta)$ between 3.5 and $50^{\circ}$.

\subsection{In Vitro Release Studies}

The in vitro release studies were carried out using PBS $(1 \times, \mathrm{pH} 7.4)$ or a sequential combination of PBS (1×, pH 7.4) followed by $\mathrm{HCl}(0.1 \mathrm{~N}, \mathrm{pH} 1.2)$, to mimic the gastrointestinal track as release mediums [8]. Briefly, $1 \mathrm{~mL}$ of concentrated PCL@C27 nanoformulation was centrifuged (10 min, $16,060 \times g, 4{ }^{\circ} \mathrm{C}$ ) to separate the supernatant from the nanoformulation. The resulting pellet was resuspended in $1 \mathrm{~mL}$ of release medium. The eppendorfs $(1.5 \mathrm{~mL})$ were kept in a bath-shaker at $37^{\circ} \mathrm{C}$ and $90 \mathrm{rpm}$. At predetermined time intervals, the nanosuspension was centrifuged $(10 \mathrm{~min}$, $16,060 \times g, 4^{\circ} \mathrm{C}$ ) and the supernatant removed and replaced by fresh release medium. All collected supernatants were stored at $4{ }^{\circ} \mathrm{C}$ until quantification. Experiments were performed in triplicate and under sink conditions.

\subsection{In Vitro Cellular Studies}

\subsubsection{Cell Lines and Culture Conditions}

Human neuroblastoma differentiated cells (SH-SY5Y cell line), epithelial colorectal adenocarcinoma cells (Caco-2 cell line), and cerebral microvascular endothelial cells (hCMEC/D3 cell line) were used as in vitro models. Details on the culture conditions are described in the literature [8] and in the Supplementary Materials.

\subsubsection{Cell Viability Assays}

After the confluence was reached, SH-SY5Y, Caco-2 and $h$ CMEC/D3 cells were exposed to different concentrations of the chromone under study $(2.5,5.0$, and $10.0 \mu \mathrm{M})$ and PCL NPs $(25-100 \mu \mathrm{g} / \mathrm{mL}$ of nanoformulation powder) in fresh cell culture medium. The cell viability was evaluated using the 3-(4,5-dimethylthiazol-2-yl)-2,5-diphenyltetrazolium bromide (MTT) reduction assay [28]. After $24 \mathrm{~h}$ of exposure (SH-SY5Y and Caco-2 cells), or $5 \mathrm{~h}$ in the case of $h \mathrm{CMEC} / \mathrm{D} 3$ cells, the cell culture medium was aspirated, and fresh cell culture medium containing $0.5 \mathrm{mg} / \mathrm{mL}$ MTT was added. Afterwards, SH-SY5Y and Caco- 2 cells were incubated for $1 \mathrm{~h}$ and $h \mathrm{CMEC} / \mathrm{D} 3$ cells were incubated for $4 \mathrm{~h}$, at $37^{\circ} \mathrm{C}$, in a humidified $5 \% \mathrm{CO}_{2}-95 \%$ air atmosphere. Then, the cell culture medium was removed, and the formed formazan crystals dissolved in 100\% DMSO. The absorbance was measured at $550 \mathrm{~nm}$ in a multi-well plate reader (PowerWaveX BioTek Instruments, Winooski, VT, USA). The results are expressed as a percentage of the control (nontreated) of three independent experiments (performed in triplicate).

\subsubsection{Cellular Uptake and Intracellular Localization Studies}

The capacity of PCL NPs to be internalized in SH-SY5Y and $h$ CMEC/D3 cells was determined using a fluorescent probe (coumarin C6) encapsulated inside PCL NPs (PCL@C6 NPs) and measured by fluorescence spectroscopy. After incubation with PCL@C6 NPs at 50 and $100 \mu \mathrm{g} / \mathrm{mL}$ (conditions 
described in cell viability analysis section), cells were washed thrice with fresh HBSS (+/+) to remove the excess of PCL@C6 NPs. Then, HBSS (+/+) was added and the intracellular fluorescence assessed in a multi-well plate reader (excitation and emission wavelengths at 485 and $528 \mathrm{~nm}$, respectively). For the intracellular localization, after treatment with PCL@C6 NPs $(50 \mu \mathrm{g} / \mathrm{mL})$, cells were washed thrice with fresh HBSS (+/+) and treated with $5 \mu \mathrm{g} / \mathrm{mL}$ of Hoechst 33,342 for $30 \mathrm{~min}$ at $37{ }^{\circ} \mathrm{C}$ in the dark. Afterwards, the cells were washed twice with fresh HBSS (+/+) and images were captured with an automated microscope (Lionheart FX, BioTek, Winooski, VT, USA). After this, the images were superimposed to determine the intracellular localization of the NPs.

\subsubsection{Evaluation of MAO-B Activity by Fluorescence Kynuramine Assay}

The capacity of C27 and nanoformulations to inhibit MAO-B in a cell SH-SY5Y-based model was performed, as described by Santillo et al., with minor modifications [29]. Briefly, after a prior inhibition of MAO-A with a standard MAO-A inhibitor (clorgyline), the activity of MAO-B was measured by the metabolization of kynuramine to 4-hydroxyquinoline, which presents fluorescence properties. After the confluence was reached, SH-SY5Y cells were incubated with clorgyline $(100 \mathrm{nM})$ for $30 \mathrm{~min}$. Then, cells were co-incubated with kynuramine $(60 \mu \mathrm{M})$ and test compounds $\left(\mathrm{C}_{\mathrm{C} 27}=1 \mu \mathrm{M}\right)$ for $8 \mathrm{~h}$ at $37^{\circ} \mathrm{C}$. The reaction was stopped by the addition of $\mathrm{NaOH}(0.5 \mathrm{M})$ to the well and the fluorescence was measured in a multi-well plate reader (excitation and emission wavelengths at 360 and $460 \mathrm{~nm}$, respectively). Selegiline (100 $\mathrm{nM}$ ) was used as a standard inhibitor of MAO-B and cells without treatment and treated only with kynuramine were used as controls. The results are expressed as a percentage of the control (nontreated), normalized with the protein content of the three independent experiments (performed in triplicate).

\subsubsection{Protein Quantification}

The activity of MAO-B was normalized to the protein content of the cell lysate, which was determined by a bicinchoninic acid (BCA) assay, as described by other authors [8], using bovine serum albumin as a standard.

\subsubsection{Cellular Permeability Studies}

The permeability of PCL@C6 NPs in human intestinal epithelium was evaluated using Caco-2 cells monolayer as an in vitro model [30]. The experimental details were performed as described in [8] and are presented in the Supplementary Materials.

\subsubsection{Rhodamine 123 Accumulation Assay}

The P-glycoprotein (P-gp) inhibitory activity of both C27 and PCL@C27 NPs was determined by measuring the intracellular accumulation of rhodamine (RHO) 123 in Caco-2 and hCMEC/D3 cells, in the absence or presence of P-gp inhibitors, as described in the literature [31]. Briefly, after reaching the confluence, cells were pre-treated with C27 $(10 \mu \mathrm{M})$ and PCL@C27 NPs $(100 \mu \mathrm{g} / \mathrm{mL})$ for $30 \mathrm{~min}$. Then, $20 \mu \mathrm{M}$ RHO 123 was added and the cells were incubated for $90 \mathrm{~min}$ at $37^{\circ} \mathrm{C}$. Elacridar, a potent third-generation P-gp inhibitor $(10 \mu \mathrm{M})$, was used as a positive control. After this time, cells were washed with PBS, lysed with DMSO, and the intracellular levels of RHO 123 were quantified by fluorimetry using a multi-well plate reader (PowerWaveX BioTek Instruments, Winooski, VT, USA) (excitation and emission wavelengths were 485 and $535 \mathrm{~nm}$, respectively). Data was expressed as the percentage of RHO 123 accumulation relative to control cells (untreated with P-gp inhibitors), arbitrarily set at $100 \%$.

\subsection{Statistical Analysis}

Physicochemical and in vitro data are presented as the mean \pm standard deviation (SD). Data analysis for all the studies are specified in the Supplementary Materials. 


\section{Results}

\subsection{Preparation and Characterization of PEGylated PCL-Based Nanoformulations}

The encapsulation of chromone C27 inside PEGylated polycaprolactone nanoparticles (PCL NPs) was successfully obtained by the nanoprecipitation method using polysorbate 80 (Tween ${ }^{\circledR} 80$, T80) as a stabilizer agent. The first step was to establish the $\mathrm{C} 27$ optimal concentration to be used during the encapsulation process, being PCL NPs fed with different chromone C27 amounts (2.5, 5 and 10\% of PCL, $w / w)$. It is important to note that feeding PCL NPs with amounts of C27 higher than $10 \%$ caused the destabilization of the nanoformulation, with the concomitant formation of aggregates (data not shown). After complete evaporation of the acetone, all stable nanoformulations were ultrafiltrated to remove any trace of free chromone C27 and also of T80 that were not adsorbed to the PCL NPs surface.

The resulting PCL@C27 nanoparticles were analyzed and the data of encapsulation efficiency $(\mathrm{EE} \%)$ and drug loading capacity (DLC\%) determinations are summarized in Figure 2a (detailed information in the Supplementary Materials).

a)

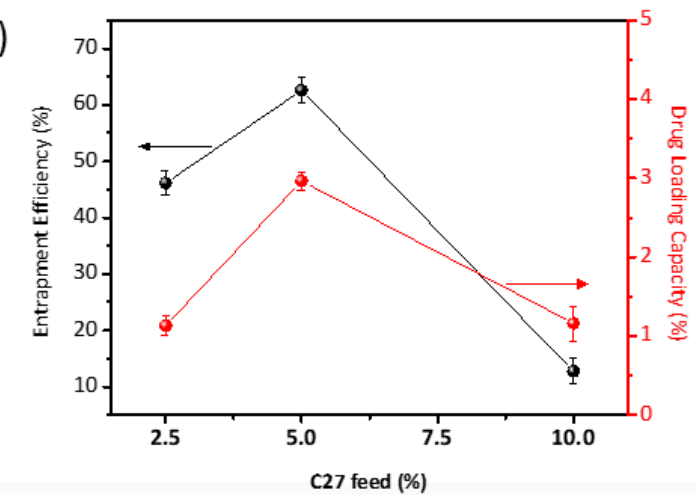

b) PCLNPS
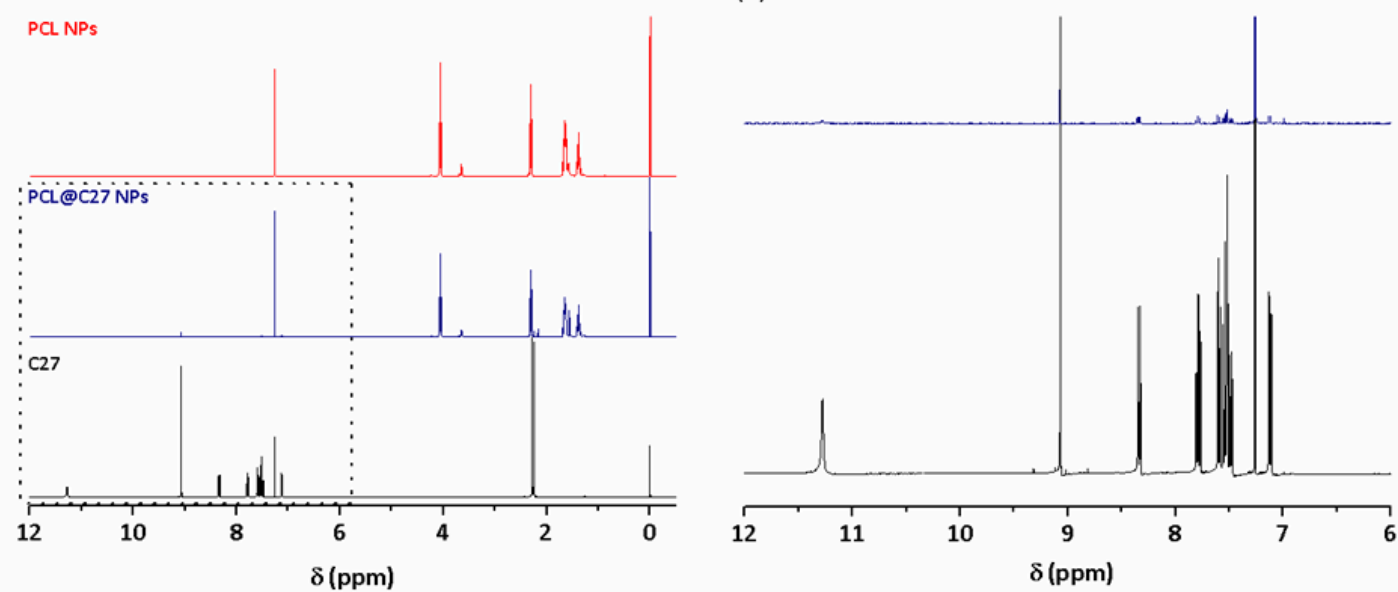

Figure 2. Physicochemical characterization of PCL@C27 nanoformulation by (a) determination of the encapsulation efficiency (EE\%) and drug loading capacity (DLC\%) of NPs fed with different amounts of chromone C27 (2.5, 5, and 10\%). (b) Structural characterization of C27, PCL NPs, and PCL@C27 NPs using ${ }^{1} \mathrm{H}$ NMR between 0 and 12 ppm, and (c) respective magnification between 12 and 6 ppm of $\mathrm{C} 27$ ${ }^{1} \mathrm{H}$ NMR spectra. Values of entrapment efficiency (EE\%, black) and drug loading capacity (DLC\%, red) obtained for PCL@C27 NPs prepared with different amounts of feeding C27. Measurements of C27 quantification were performed in triplicate and results are presented as mean $\pm \mathrm{SD}$.

As observed in Figure 2a, the highest EE\% $(62.5 \pm 2.3 \%)$ and DLC\% $(2.96 \pm 0.12 \%)$ values were obtained for the NPs with a 5\% C27:PCL ratio. As a result, under these conditions, the final C27 concentration $\left(\mathrm{C}_{\mathrm{C} 27}\right)$ value of PCL@C27 NPs was $263.3 \pm 12.1 \mu \mathrm{M}$, presenting a concentration 
approximately 400,000-fold higher than the concentration required for the therapeutic effect (MAO-B $\mathrm{IC}_{50}=670 \pm 130 \mathrm{pM}$ ).

To confirm the PCL NPs structural composition ${ }^{1} \mathrm{H}$ NMR spectra were acquired (Figure 2b). The ${ }^{1} \mathrm{H}$ NMR spectra of the nanoformulations (red and blue lines) showed the PCL characteristic peak resonances at $1.38,1.65,2.30$, and $4.06 \mathrm{ppm}$, which are related to the $\mathrm{CH}_{2}$ protons of the PCL backbone [32]. Also, the peak located at $3.63 \mathrm{ppm}$, assigned to a $\mathrm{CH}_{2}$, corroborates the presence of $\mathrm{T} 80$ in both PCL NPs [33]. In addition, in the PCL@C27 NPs spectra (blue line), the signals caused by the presence of the benzopyrone proton peaks were observed at 2.25 and $2.28 \mathrm{ppm}$, which are related to the two methyl groups located on the exocyclic aromatic ring, and between 9.1-7.1 ppm. The data confirm the presence of the $\mathrm{C} 27$ chromone in the NPs. The detailed $\mathrm{C} 27^{1} \mathrm{H}$ NMR data (black line) was included in the Supplementary Materials.

\subsection{Differential Scanning Calorimetry and Powder X-ray Diffraction Analysis}

Chromone C27, unloaded, and loaded PCL NPs were subjected to thermal analysis to obtain information regarding their crystalline morphology, as well as information on putative interactions between C27 and the PCL polymeric matrix [34,35]. The differential scanning calorimetry (DSC) curves are depicted in Figure 3a.
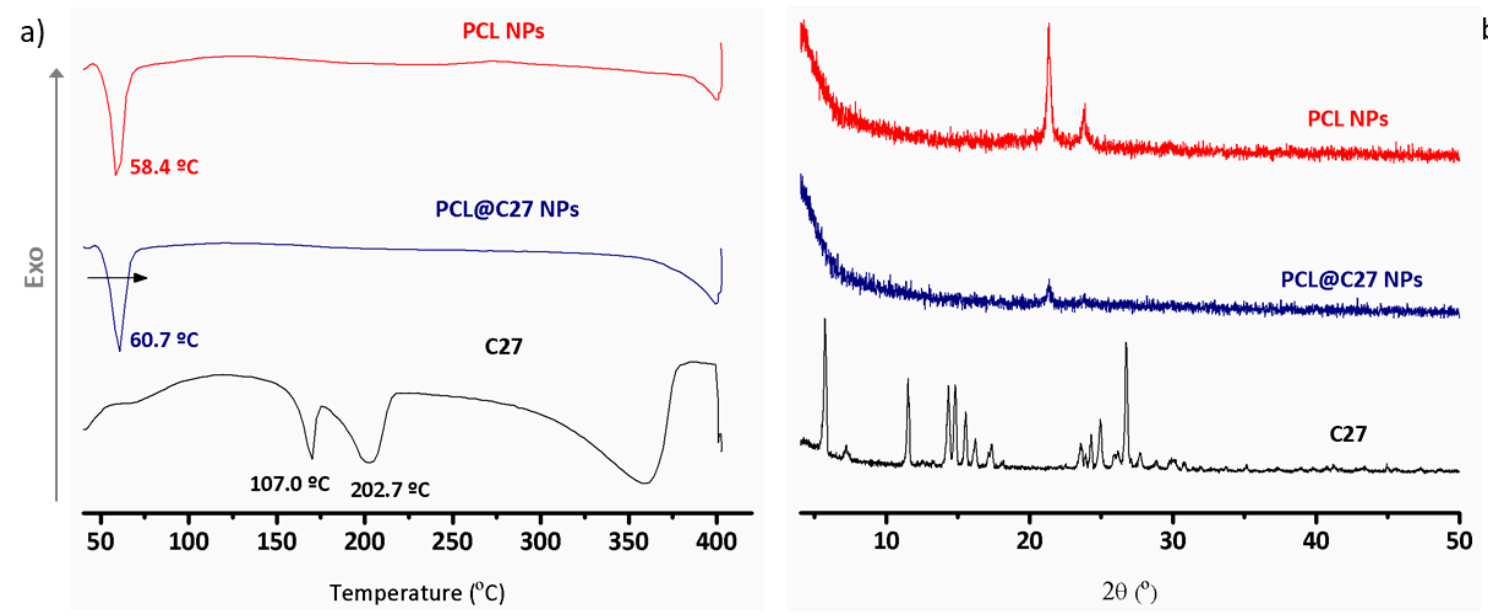

b)

Figure 3. Physicochemical characterization of chromone C27, PCL NPs, and PCL@C27 NPs using (a) differential scanning calorimetry (DSC) between 40 and $400{ }^{\circ} \mathrm{C}$, and (b) powder X-ray diffraction (PXRD) in the range of $4-50^{\circ} \mathrm{C}$.

For chromone C27 (black curve) a typical thermogram of a crystalline structure with two endothermic peaks at $170.0^{\circ} \mathrm{C}$ and $202.7^{\circ} \mathrm{C}$ was obtained. Since chromone $\mathrm{C} 27$ thermogravimetric analysis (data not shown) did not show any weight loss in this range of temperatures, these peaks were not due to evaporation of water. Instead, the first peak could be related to a glass transition process [36] and the second peak to the $\mathrm{C} 27$ melting transition, characterized by a $T_{\max }=233-236{ }^{\circ} \mathrm{C}$, which is approximately the same value of the C27 melting point obtained by capillary method (Supplementary Materials).

As none of these peaks appeared in the PCL@C27 NPs DSC curve (in blue), it can be concluded that $\mathrm{C} 27$ is encapsulated, probably in an amorphous or disordered phase [37]. The melting endothermic peak at $58.4^{\circ} \mathrm{C}$ presented by the PCL NPs (in red) suffered a shift of $2{ }^{\circ} \mathrm{C}$ in the PCL@C27 NPs $\left(60.7^{\circ} \mathrm{C}\right.$, Figure 3a), a change that discloses a strong interaction between C27 and the PCL matrix $[8,38]$.

As the crystallinity of the encapsulated C27 into PCL NPs can influence the drug release properties of the nanoparticles [39], powder X-ray diffraction (PXRD) data were acquired.

The diffractograms of C27, unloaded, and loaded NPs are depicted in Figure 3b. The diffractogram of C27 exhibited sharp peaks that are intrinsically related to the crystalline nature of chromone. 
For nanoformulations, a semi-crystalline structure with two sharp peaks between 20 and $25^{\circ}$ was detected [40]. Moreover, a decrease in polymer crystallinity was observed when comparing both PCL and PCL@C27 nanoformulations, which can be related to an interaction between the chromone and the polymer. The diffractogram of PCL@C27 NPs does not have any reflection pertaining to C27, which suggests its complete amorphization when loaded in the polymeric matrix [41]. These results are in good agreement with the literature [42]. Moreover, the data corroborate well with the results of DSC analysis.

\subsection{PEGylated PCL@C27 Particle Size,z-Potential, and Morphology}

The morphology and shape of PCL@C27 NPs were evaluated using scanning electron microscopy (SEM, Figure 4a).

a)

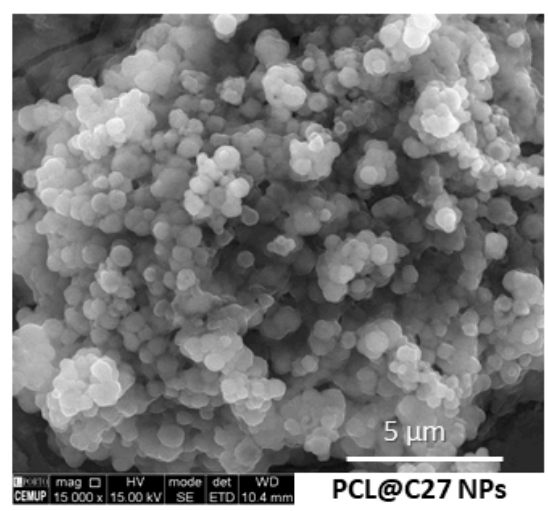

Milli-Q

$\operatorname{PBS}(1 \times,+/+)$

$\operatorname{HBSS}(+/+)$ b)

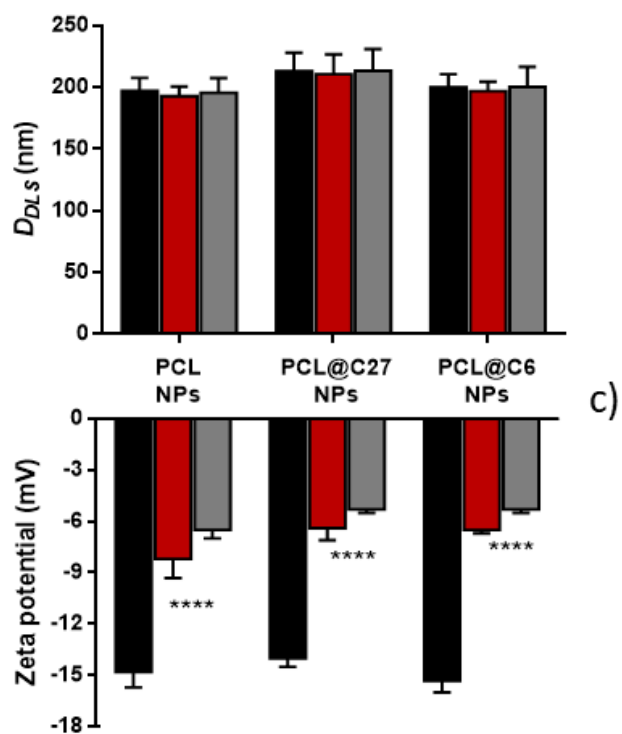

Figure 4. Morphological characterization of PCL@C27 NPs by scanning electron microscopy (SEM) (a) and hydrodynamic average sizes $\left(\mathrm{D}_{D L S}\right)(\mathbf{b})$ and zeta potential values (c) of PEGylated PCL NPs in Milli-Q water, phosphate buffered saline solution (PBS) $(1 \times,+/+)$, and Hank's balanced salt solution (HBSS) $(+/+)$, as measured by dynamic light scattering (DLS). All measurements were performed in triplicate and results are given as mean $\pm \mathrm{SD}$. Statistical comparisons were made using two-way ANOVA. In all cases, $p$-values lower than 0.05 were considered significant ${ }^{* * * *} p<0.0001$ versus Milli-Q water values).

The PCL@C27 nanoformulation presented NPs with a spherical shape and a uniform size distribution (Figure 4a), although some aggregation, probably due to the drying process, was observed. The hydrodynamic size $\left(\mathrm{D}_{D L S}\right)$ and zeta potential (z-potential) of C27-loaded and unloaded PEGylated PCL NPs were assessed in three different conditions: Milli-Q water, phosphate-buffered solution with calcium and magnesium (PBS $1 \times,+/+$ ), and Hank's balanced salt solution with calcium and magnesium (HBSS $+/+$ ) (Figure $4 \mathrm{~b}, \mathrm{c}$ ). Although particle characterization measurements are commonly conducted in Milli-Q water [43], the morphology and surface charge of NPs were also evaluated in PBS and HBSS, the mediums used in drug-controlled release and cell-based studies, respectively.

Since PEGylated PCL NPs containing a fluorescent coumarin-based probe (PCL@C6 NPs) were used for the cellular uptake, intracellular localization, and permeability studies, it was necessary to compare the morphology between both PCL@C27 and PCL@C6 nanoformulations.

For all tested media, the nanoformulations presented monodisperse profiles with $\mathrm{D}_{D L S}$ lower than $250 \mathrm{~nm}$ (Figure 4b). In fact, in physiological mediums (PBS and HBSS medium), PCL@C27 NPs had $D_{D L S}$ values between 211 and $213 \mathrm{~nm}$. As NPs sized circa $200 \mathrm{~nm}$ have been reported to 
be able to cross biological barriers, by preventing spleen filtration and reducing the opsonization by reticuloendothelial system, this is considered an encouraging result $[44,45]$. Despite no significant morphological differences being observed, the presence of chromone C27 seemed to influence the size of PCL NPs in both media, as they presented a slightly larger size when compared to unloaded NPs $(\sim 3-7 \%$ higher size values). This data is in good agreement with the literature $[25,46]$.

The stability of NPs in aqueous medium is often assured by the presence of a surface charge, as it avoids the aggregation process. Without surfactant, PCL NPs usually present a z-potential between -35 and $-30 \mathrm{mV}$ in Milli-Q water, due to the negatively charged ionized carboxylic acid groups of the polymer [37]. In our case, the presence of T80 in NPs surface led to a reduction of the z-potential value to -14.0 and $-15.3 \mathrm{mV}$ in Milli-Q water for PCL NPs and PCL@C27 (Figure 4c), respectively. In physiological medium, the z-potential values (between -5.3 and $-8.2 \mathrm{mV}$ ) were significantly different $(p<0.0001)$ from those obtained in Milli-Q water. This data is in accordance with what has been previously reported [8], and can be ascribed to the presence of interactions of opposite charged ions with the NPs surface $[47,48]$. The presence of T80 and negative charge in NPs surface could justify the high storage stability at $4{ }^{\circ} \mathrm{C}$ over three months, since both $\mathrm{D}_{D L S}$ and z-potential NPs remained unchanged and no aggregates were observed (data not shown).

The data showed non-significant differences in terms of NPs size and surface charge density, when comparing PCL@C6 to PCL@C27 NPs (Figure 4b,c). These results allow us to use the nanoformulation PCL@C6 as a model of C27 delivery carrier in cellular studies.

\subsection{In Vitro C27 Release Kinetics}

The evaluation of C27 sustainable release from PCL@C27 NPs was performed in PBS (pH 7.4) at $37^{\circ} \mathrm{C}$ for seven days, and at $\mathrm{pH} 1.2$ for $2 \mathrm{~h}$, followed by $\mathrm{pH} 7.4$ for $5 \mathrm{~h}$, to simulate the passage through the upper human gastrointestinal tract [49]. In both conditions, the in vitro release profile from PCL@C27 NPs was obtained by graphing the cumulative percentage of the released C27 with respect to the amount of chromone encapsulated as a function of the time (Figure 5).

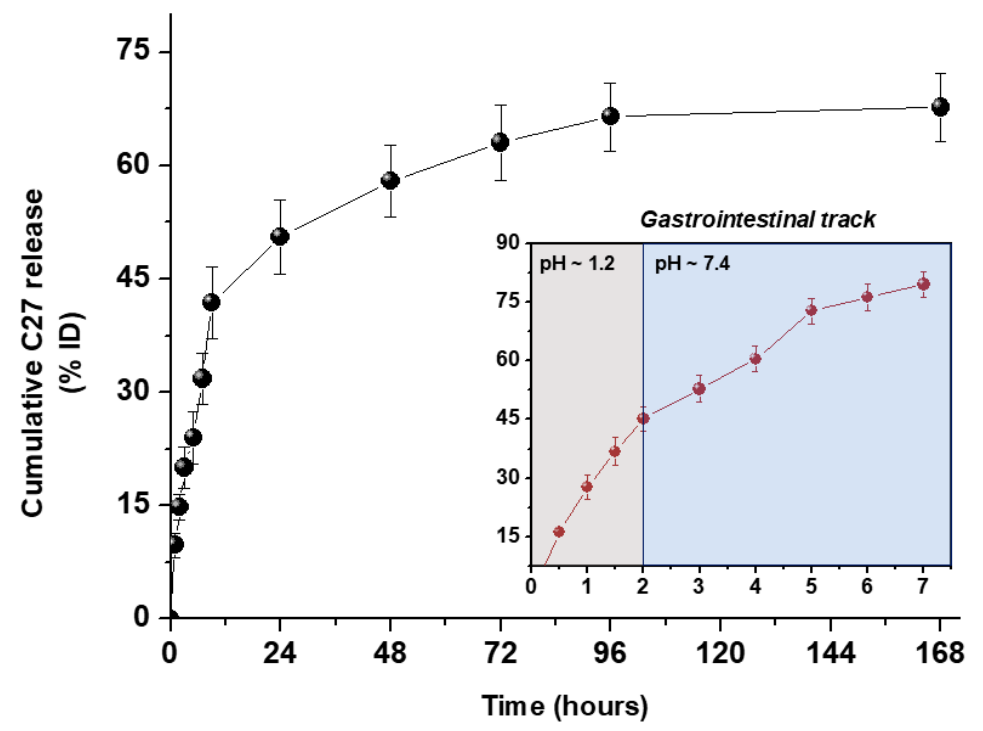

Figure 5. In vitro release profile of chromone C27 from PCL@C27 NPs in PBS (pH 7.4) conducted for seven days (black dot). Inset: In vitro release profile in $0.1 \mathrm{~N} \mathrm{HCl}, \mathrm{pH} 1.2$, for $2 \mathrm{~h}$ followed by PBS, $\mathrm{pH} 7.4$, for $5 \mathrm{~h}$ (red data). Results are presented as means $\pm \mathrm{SD}$ of three independent experiments.

The in vitro release profile showed a typical biphasic pattern, with an initial burst release in the first $9 \mathrm{~h}$, followed by a slow and continuous release up to $168 \mathrm{~h}$. The initial burst estimated for PCL@C27 NPs was $41.8 \pm 4.8 \%$ and can be related to the dissolution in the release media of C27 chromone adsorbed in the NPs surface [19]. After the initial burst, C27 was slowly released from NPs until the 
end of the experiment (seven days), reaching a plateau with a total C27 cumulative release amount of $67.7 \pm 4.4 \%$. The final $\mathrm{C}_{\mathrm{C} 27}$ in release medium was $174.2 \pm 11.5 \mu \mathrm{M}$ (approximately 275,000 -fold higher than $\mathrm{C} 27 \mathrm{MAO}-\mathrm{B} \mathrm{IC}_{50}$ value). The second phase of the biphasic release pattern is assumed to be related to: (1) a slow C27 diffusion from the PCL matrix, (2) a progressive degradation/erosion of the polymeric matrix in physiological medium, or (3) a mixed course involving both processes [50].

The in vitro release studies in gastrointestinal simulated fluids (inset of Figure 5) make it possible to conclude that the $\mathrm{C} 27$ release is accelerated in acidic medium, in a process probably related to a faster degradation of PCL. Comparing the data obtained in both media in the first 2 and $7 \mathrm{~h}$, a circa 3and 2.5-fold increase of C27 release was observed in the acidic medium, respectively. This data is in good agreement with data previously reported by our group related to the release of a coumarin-based compound from PEGylated PLGA NPs [8].

The data obtained from in vitro drug release studies was fitted to the Korsmeyer-Peppas model [12] and the results are summarized in Table 1.

Table 1. Correlation values $\left(\mathrm{R}^{2}\right)$ and release exponent $(n)$ of kinetic data analysis of chromone C27 release from PCL@C27 NPs in different medium.

\begin{tabular}{cccc}
\hline \multirow{2}{*}{ Medium pH } & \multicolumn{3}{c}{ Korsmeyer-Peppas } \\
\cline { 2 - 4 } & $\mathbf{R}^{\mathbf{2}}$ & $\boldsymbol{n}$ & $\mathbf{K ~ ( h}^{\mathbf{- 1}} \mathbf{)}$ \\
\hline 7.4 & 0.972 & 0.464 & 11.2 \\
\hline $1.2-7.4$ & 0.985 & 0.594 & 26.9 \\
\hline
\end{tabular}

The regression coefficient $\left(\mathrm{R}^{2}\right)$ of the plot of $\log M t / M \infty$ versus $\log t$ for NPs in PBS (1×) was found to be 0.972 , with values of the release exponent $(n)$ and release constant $(\mathrm{K})$ of 0.464 and 11.2, respectively. In the case of the use of a combined acidic and PBS medium $\left(R^{2}=0.985\right)$, the release exponent and release constants values were 0.594 and 26.9, respectively. To sum up, the type of medium affected the way and rate of C27 release: (a) when PBS was used as medium, the $n$ value was $<0.5$, showing that the release of C27 from NPs can be explained by Fickian diffusion [12]; (b) when an acidic medium was employed, the $n$ value was higher than 0.5 , suggesting a release process controlled by polymer erosion [51]. This assumption was corroborated by the higher release constant $\left(26.9 \mathrm{~h}^{-1}\right)$ in the first $2 \mathrm{~h}$ of the experiment.

In conclusion, C27 was successfully released from PCL NPs, with good yields and in a sustained way, regardless of its low solubility profile and strong interaction with the PCL matrix.

\subsection{In Vitro Cellular Studies}

\subsubsection{In Vitro Cytotoxicity in Neuronal, Intestinal, and Endothelial Cells}

Since IMAO-B operate by metabolic inactivation, and thus increase dopamine activity in the neuron synaptic cleft and at respective postsynaptic receptor sites [52], a human model of neuronal cells was chosen (differentiated neuroblastoma SH-SY5Y cells) to evaluate the cytotoxic profile of free C27 and PCL@C27 NPs. The neuroblastoma SH-SY5Y cell line is widely used in studies requiring neuronal-like cells, as they express a number of dopaminergic neuronal markers [53,54]. Furthermore, the cytotoxic effects of chromone C27 and PCL@C27 NPs were also evaluated in epithelial colorectal adenocarcinoma (Caco-2) and in human brain microvascular endothelial ( $h \mathrm{CMEC} / \mathrm{D} 3)$ cells, as they are widely used in vitro models to determine the intestinal and blood-brain barrier (BBB) permeability, respectively $[25,30]$.

The cellular viability of C27 $(2.5,5.0$, and $10.0 \mu \mathrm{M})$ and PCL@C27 NPs $(25-100 \mu \mathrm{g} / \mathrm{mL}$ of nanoformulation powder) was indirectly determined by the measurement of the cellular metabolic activity using the MTT reduction method, $24 \mathrm{~h}$ after exposure (Figure 6). The PCL@C27 NPs concentration range was chosen in order to test nanoformulation at same $\mathrm{C} 27$ concentration as free $\mathrm{C} 27$ and taking into account the final $\mathrm{C}_{\mathrm{C} 27}(263.3 \pm 12.1 \mu \mathrm{M})$. Furthermore, an end-point of $24 \mathrm{~h}$ 
was performed to avoid possible interferences of cytotoxic effects of free C27, since, as observed in controlled release data (Figure 5), after this period of time, around 50\% of C27 is released from NPs.

a)

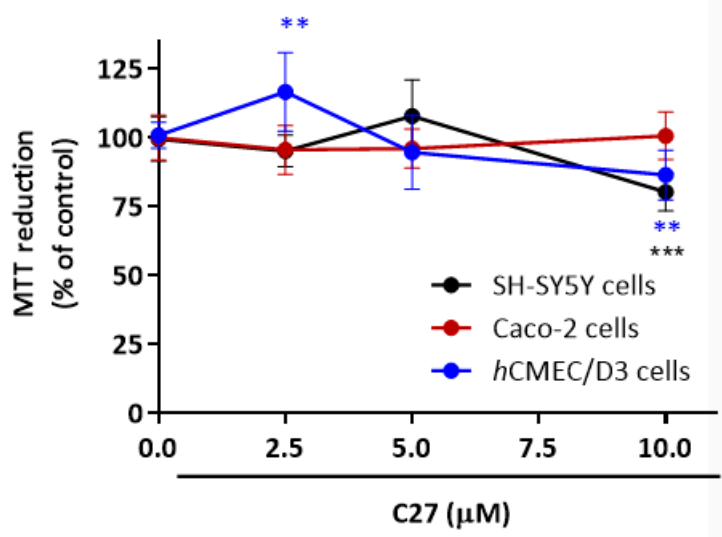

b)

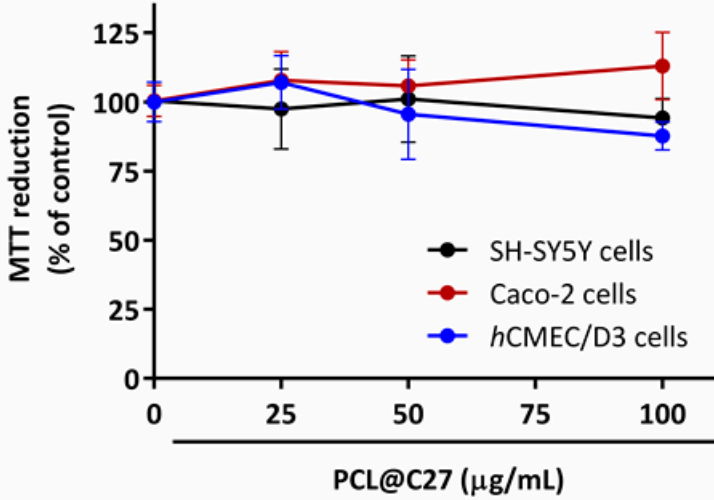

c)

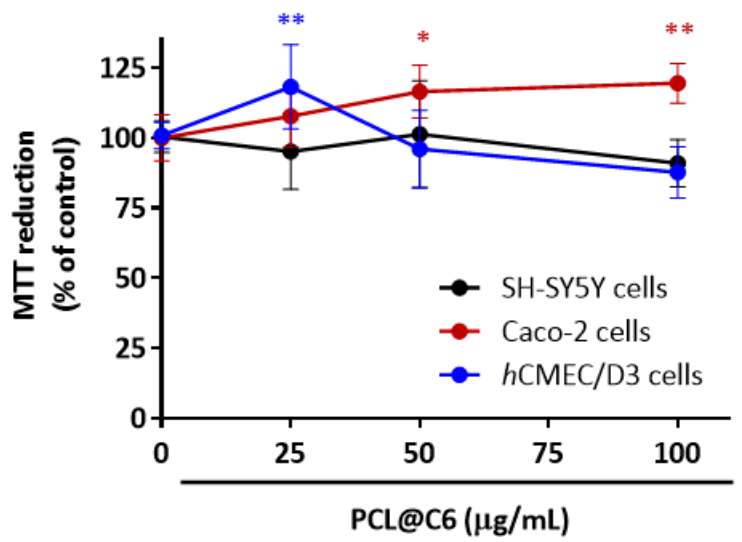

Figure 6. Cytotoxicity profile of C27 at 2.5, 5, and $10 \mu \mathrm{M}$ (a) as well as nanoformulations of PCL@C27 (b) and PCL@C6 NPs (c) at 25, 50, and $100 \mu \mathrm{g} / \mathrm{mL}$ in different cells lines, evaluated by the MTT reduction assay $24 \mathrm{~h}$ after exposure. Results are expressed as mean percentage of MTT reduction \pm SD of three independent experiments. In all cases, $p$-values lower than 0.05 were considered significant $\left({ }^{*} p<0.05\right.$, ** $p<0.01,{ }^{* * *} p<0.001$ versus control cells).

No significant cytotoxic effects were observed in Caco-2 cells when exposed to C27, when compared to control cells, and for the conditions tested (Figure 6a). On the contrary, a slight but significant decrease in the metabolic activity was observed when SH-SY5Y $(80.3 \pm 2.4 \%, p<0.01)$ and $h \mathrm{CMEC} / \mathrm{D} 3$ cells $(86.5 \pm 3.2 \%, p<0.05)$ were exposed to $\mathrm{C} 27$ at the highest concentration $(10 \mu \mathrm{M})$ for $24 \mathrm{~h}$.

In the case of PCL@C27 NPs, in the present experimental conditions, no significant cytotoxic effects were noticed (Figure $6 \mathrm{~b}$ ), even for the highest concentration tested $(100 \mu \mathrm{g} / \mathrm{mL})$, which corresponded to a final encapsulated C27 concentration of around $10.6 \mu \mathrm{M}$.

Although efforts were made to evaluate the uptake and permeability of chromone $\mathrm{C} 27$ and PCL@C27 NPs across SH-SY5Y, Caco-2, and hCMEC/D3 cells, these studies were hampered by the chromone spectral features and the sensitivity of the analytical method. Therefore, a model probe was used to validate the carrier properties of the PCL nanoformulation. As previously mentioned, a probe based on coumarin scaffold (coumarin C6, Figure 1) [55], a benzopyran analogue, was chosen to attain the goal, due to its structural similarity and unique fluorescent properties. After the preparation and morphologic characterization of PCL@C6 NPs, the cytotoxic profile of the PCL@C6 nanoformulation was evaluated using the same conditions described for the PCL@C27 NPs studies. For all tested cell lines, no significant reduction in the metabolic activity was detected, for concentrations up to $100 \mu \mathrm{g} / \mathrm{mL}$, and after $24 \mathrm{~h}$ of incubation. 
Summing up the data herein obtained reinforced the benefit of using PEGylated PCL NPs as carriers of bioactive compounds that present bioavailability drawbacks.

\subsubsection{In Vitro Cellular Uptake and Intracellular Localization in Neuronal and Endothelial Cells}

The intracellular localization of PEGylated PCL NPs was verified by fluorescence microscopy in neuronal and endothelial (SH-SY5Y and $h$ CMEC/D3) cells that express MAO-B [56,57]. For this, cells were exposed to PCL@C6 NPs ( $50 \mu \mathrm{g} / \mathrm{mL})$ for 24 and $5 \mathrm{~h}$, respectively. After that, they were washed with HBSS $(+/+)$ to remove the excess PEGylated PCL NPs and the cell's nucleus was marked with Hoechst 33,342 (blue stain) and the nucleic acid (either DNA or RNA) with acridine orange (orange stain). From the data (Figure 7a), it was observed that PCL@C6 NPs (green stain) were dispersed in the cytoplasm of the cells.

a)
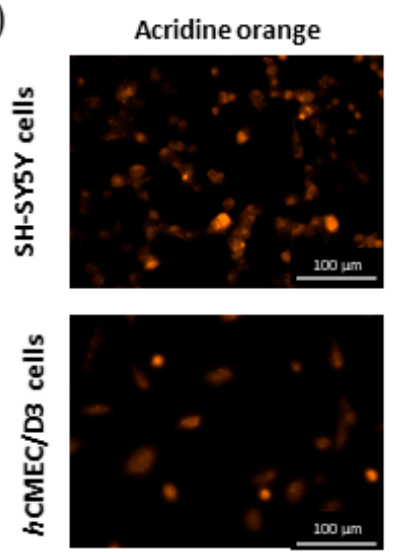

PCL@C6 NPs
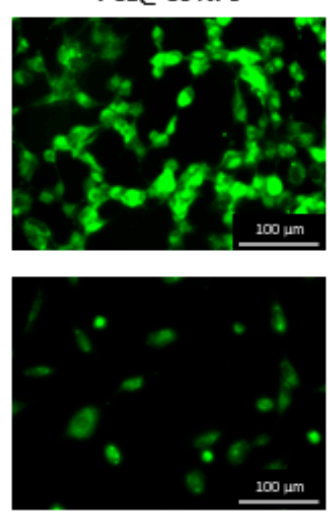
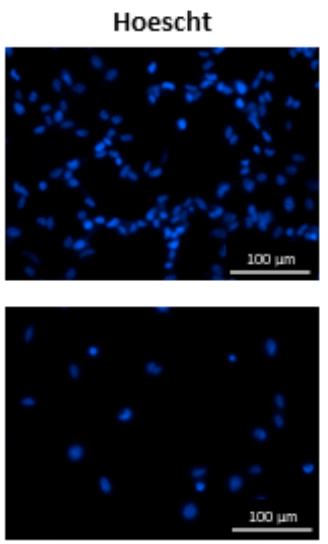
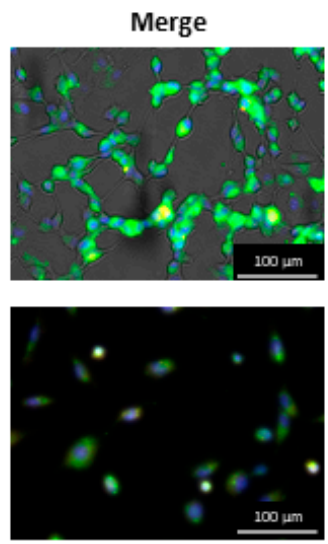

b)
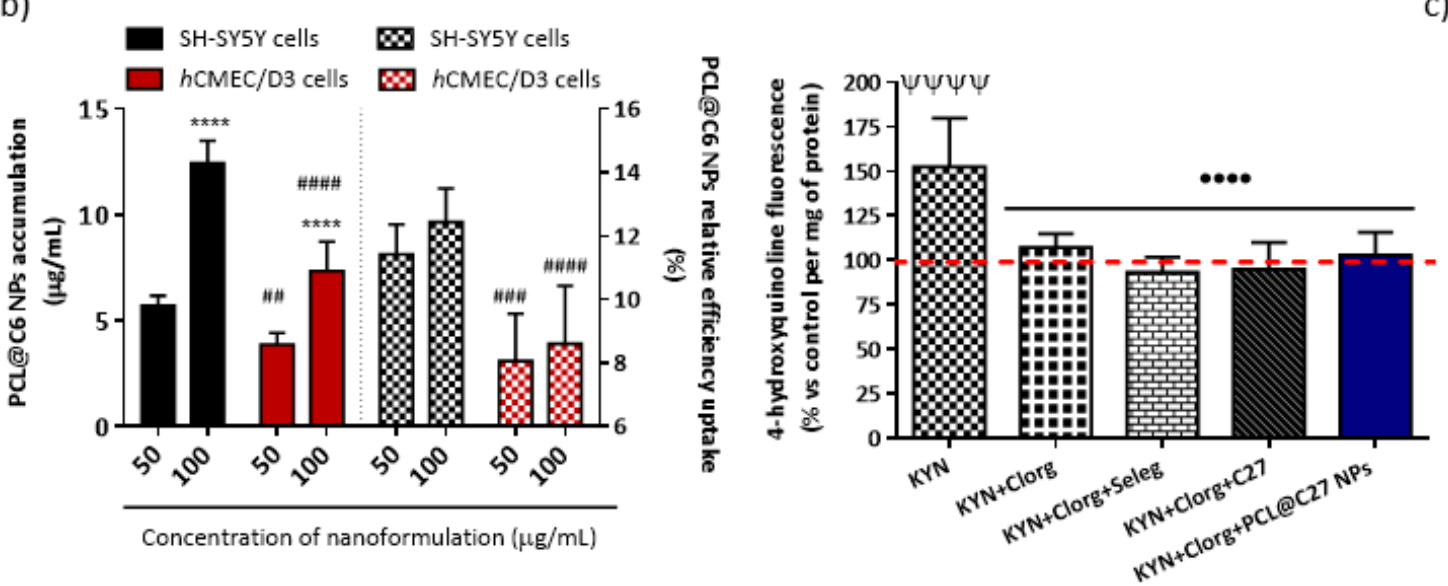

Figure 7. Representative images of acridine-orange and Hoescht stained SH-SY5Y and $h$ CMEC/D3 cells treated with PCL@C6 NPs at $50 \mu \mathrm{g} / \mathrm{mL}$ for 24 and $5 \mathrm{~h}$, respectively (a); accumulation (solid bars) and relative efficiency uptake (patterned bars) of PCL@C6 NPs (50 and $100 \mu \mathrm{g} / \mathrm{mL}$ ) in SH-SY5Y and $h \mathrm{CMEC} / \mathrm{D} 3$ cells after 24 and $5 \mathrm{~h}$ of exposure, respectively $(\mathbf{b})$; evaluation of the MAO-B inhibitory capacity in SH-SY5Y cells after $8 \mathrm{~h}$ of exposure, using kynuramine (KYN) as the substrate and clorgyline (Clorg) and selegiline (Seleg) as standard inhibitors of MAO-A and MAO-B, respectively (c). The results are expressed as mean $\pm \mathrm{SD}(n=3)$ and statistical comparisons were made using two-way ANOVA and one-way ANOVA, in cases $(\mathbf{b})$ and $(\mathbf{c})$, respectively. In all cases, $p$-values lower than 0.05 were considered significant ${ }^{* * * *} p<0.0001$ by comparison of different concentrations tested concentration; $\# p<0.01$, , \#\# $p<0.001$, and ${ }^{\# \# \#} p<0.0001$ by comparison the results obtained between the two cell

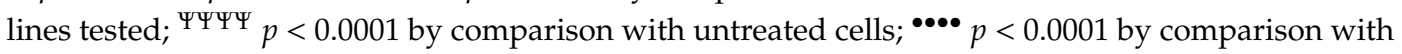
cells treated only with kynuramine). The dashed red line represents the control data. 
As described above, after the exposure to PCL@C6 NPs at 50 and $100 \mu \mathrm{g} / \mathrm{mL}$, cells were washed with HBSS $(+/+)$ and the remaining fluorescence was measured by exciting the media with a radiation of $485 \mathrm{~nm}$. The results are presented as the intracellular accumulation and relative efficiency uptake of PCL@C6 NPs (50 and $100 \mu \mathrm{g} / \mathrm{mL}$, Figure 7b).

The cellular uptake of PCL@C6 NPs is supposed to occur via endocytosis [58], and in both cell lines is significantly different and influenced by the initial concentration (IC) used in the treatment of the cells (Figure 7a). For the same concentration, PCL@C6 NPs uptake is higher in neuronal cells than in endothelial cells (Figure 7a, solid bars). Actually, a proportionality between the concentration and the uptake was established: the exposure to PCL@C6 NPs at $100 \mu \mathrm{g} / \mathrm{mL}$ resulted in a 2.2- and 1.9-fold higher cellular uptake ${ }^{* * * *} p<0.0001$, Figure $7 \mathrm{a}$, solid bars) in neuronal and endothelial cells, respectively, when compared to the $50 \mu \mathrm{g} / \mathrm{mL}$ concentration. However, after comparing the efficiency of cellular uptake for the concentrations tested (50 and $100 \mu \mathrm{g} / \mathrm{mL}$ ), no significant difference was observed (Figure 7a, patterned bars).

Since the structure and morphology of PCL@C27 and PCL@C6 NPs are similar, we suggested that both nanoformulations presented identical cellular uptake profiles, which allowed us to correlate the concentrations of nanoformulations PCL@C6 and PCL@C27 inside the cells. After the end-points, minimum nanoformulation concentrations of $5.7 \pm 0.2$ and $3.9 \pm 0.2 \mu \mathrm{g} / \mathrm{mL}$ were determined for SH-SY5Y and $h$ CMEC/D3 cells (Figure 7a, solid bars), respectively, which corresponded to a final C27 concentration between 410 and $606 \mathrm{nM}$. This range of concentration is 651- to 963-fold higher than the C27 MAO-B IC 50 value.

To demonstrate the MAO-B inhibitory activity of the systems in a cell-based model (SH-SY5Y), additional studies were performed in the presence and absence of $\mathrm{C} 27$ and nanoformulation PCL@C27 [29]. The activity of MAO-A was inhibited by pre-treatment with clorgyline (100 nM) and the fluorescence intensity was normalized to the protein content. The same procedure was followed with the MAO-B inhibitor selegiline (100 nM).

After $8 \mathrm{~h}$ of experiments, and in the absence of MAO inhibitors, an increment of fluorescence intensity caused by the metabolization of kynuramine to 4-hydroxyquinoline (fluorescent metabolite) was observed, when compared with untreated cells ( ${ }^{\Psi \Psi \Psi \Psi} p<0.0001$, Figure 7c). Meanwhile, when both $\mathrm{MAO}-\mathrm{A}$ and MAO-B inhibitors were used, a reduction in the intensity of fluorescence was observed, when compared with cells treated only with kynuramine $\left(\bullet^{\cdots} p<0.0001\right.$, Figure $\left.7 \mathrm{c}\right)$. The same protocol was applied with selegiline. In this case, a slight decrease in fluorescence, when compared with the treatment done only with clorgyline, was detected. This effect is related to the inhibition of both MAO isoforms. Since the treatment with C27 and PCL@C27 NPs showed the same tendency as the data obtained with selegiline, it was concluded that $\mathrm{C} 27$ works as a MAO-B inhibitor in neuronal cells.

The combined data of microscopy analysis, cellular uptake, and MAO-B activity in cell-based models suggested that PEGylated PCL NPs can deliver C27 into the cellular cytoplasmatic matrix. Even further, it was shown that C27 and PCL@C27 NPs are capable of inhibiting MAO-B in neuronal cells.

\subsubsection{In Vitro Permeability Studies in Epithelial and Endothelial Cells}

Several in vitro BBB models, also used by the (bio)pharma industry, have been developed to assist the selection and preclinical evaluation of CNS drug candidates [59]. Among those based on primary cultures of cerebral endothelial cells or immortalized cell lines, the human brain endothelial cell line $(h \mathrm{CMEC} / \mathrm{D} 3)$ is one of the most studied in drug transport and uptake experiments [60]. However, other models based on epithelial cell lines have been also used to predict the permeability of CNS drug candidates, due to their advantages in terms of costs $[59,60]$. In fact, the Caco-2 human intestinal epithelial cell line is one of the most widely in vitro models used to predict human drug absorption, mainly for small intestine absorption [61].

Accordingly, the ability of PEGylated PCL NPs to cross biological barriers was evaluated in two different cell lines (Caco-2 and $h \mathrm{CMEC} / \mathrm{D} 3$ cells) [8]. These cell lines retain the expression of most 
transporters and receptors expressed in vivo in the human intestine and BBBs and have been widely used in several permeability studies related to Alzheimer's and Parkinson's diseases [8,62,63]. Both cell lines were cultured in a cell culture insert filter (Transwell) and used after obtaining cellular monolayers with high integrity, a parameter that was verified by the measurement of transendothelial electrical resistance values. The number of PCL@C6 NPs accumulated in basal medium was normalized with the weight of protein presented in the respective Transwell.

The data presented in Figure 8 show that PCL@C6 NPs $(100 \mu \mathrm{g} / \mathrm{mL})$ exhibited two permeability profiles with a biphasic tendency, which can be ascribed to a mixed passive and transport-mediated mechanism [8,64]. Although, in terms of the particle size, the transport mechanism established for particles up to $200 \mathrm{~nm}$ is the receptor-mediate endocytosis [65], the use of T80 as a coating agent in PCL NPs could enhance the paracellular permeation in epithelial and endothelial cell monolayers [66,67]. In fact, it was demonstrated in vivo that the accumulation of donepezil in the brain was significantly higher when the drug was encapsulated in PLGA NPs, and that Tween 80 can improve the opening of the tight junctions at the BBB and inhibit the P-glycoprotein efflux system [68].

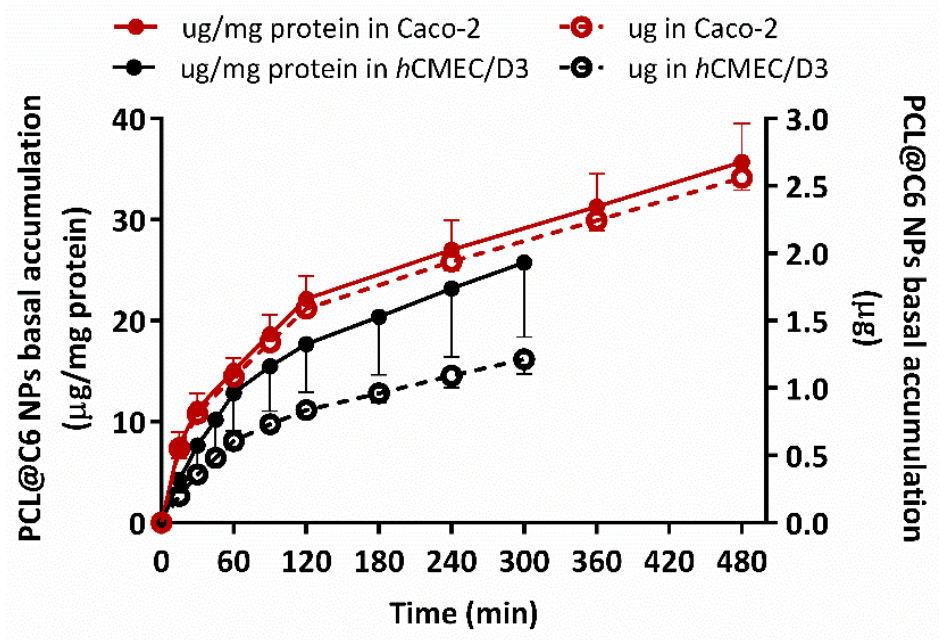

Figure 8. Amount of PCL@C6 NPs, with ( $\mu \mathrm{g} / \mathrm{mg}$ of protein, solid circles and line) or without ( $\mu \mathrm{g}$, empty circles points and dash line) protein mass normalization, accumulated in basal medium after $5 \mathrm{~h}$ and $8 \mathrm{~h}$ of permeability experiment in $h$ CMEC/D3 (black data) and Caco-2 (red data) cells with a $100 \mu \mathrm{g} / \mathrm{mL}$ initial concentration. Results are expressed as mean \pm SD of three independent experiments.

In Caco-2 cell monolayers, a final accumulation of $35.7 \pm 3.8 \mu \mathrm{g} / \mathrm{mg}$ protein (solid red circles), were obtained with an apparent permeability coefficient $\left(\mathrm{P}_{\mathrm{app}}\right)$ value calculated of $4.7 \times 10^{-7} \mathrm{~cm} / \mathrm{s}[69]$. Meanwhile, after $5 \mathrm{~h}$ of experiment, a final PEGylated PCL NPs concentration of $25.7 \pm 7.4 \mu \mathrm{g} / \mathrm{mg}$ protein (solid black circles) was found in basal medium, with a concomitant $P_{\text {app }}$ value of $1.2 \times 10^{-7} \mathrm{~cm} / \mathrm{s}[69]$. The combined data showed that PEGylated PCL NPs were capable to cross both intestinal and BBB barriers in a time-dependent manner.

In terms of nanoformulation mass (empty circles, Figure 8), $2.56 \pm 0.09$ (red empty circles, Figure 8) and $1.21 \pm 0.11 \mu \mathrm{g}$ (black empty circles, Figure 8) were detected at the end of experiment, in the basal medium of Caco-2 and hCMEC/D3 cells, respectively. The slight differences between the values obtained in permeability assays could be associated with the type of cells and intrinsic mechanisms of passive transport [70].

In line with the results of cellular uptake, we hypothesize that PCL@C27 nanoformulation is also able to cross intestine and BBB in vitro monolayers in the same extension as PCL@C6 NPs. Thus, extrapolating the results obtained for PCL@C6 NPs, a final C27 concentration of 117.7 and 55.8 nM (at least one order of magnitude higher than $\mathrm{C} 27 \mathrm{MAO}-\mathrm{B}_{50}$ value) could be expected.

PEGylated PCL NPs showed the ability to circumvent in vitro BBB cell monolayer hindrances and deliver an IMAO-B at concentrations higher enough to induce a therapeutic effect. 


\subsubsection{Rhodamine 123 Accumulation in Epithelial and Endothelial Cells}

The inhibition of efflux pumps is described to be a parameter of utmost importance in drug delivery [71]. In fact, after the discovery that polymeric pharmaceutical excipients can inhibit efflux pumps, various other polymers have been studied regarding their potential efflux pump inhibitory activity [72]. Excipients containing polyethylene glycol and PEGylated surfactants, such T80 or poloxamers, have been described to efficiently inhibit efflux pumps, namely P-glycoprotein (P-gp) [73-75].

In this work, Caco-2 and $h \mathrm{CMEC} / \mathrm{D} 3$ cells were used as in vitro models and the P-gp activity assessed using RHO 123 as a P-gp fluorescent substrate. Therefore, a decrease in P-gp activity results in a decreased amount of RHO 123 effluxed by this pump, which is followed by an increase in the intracellular fluorescence intensity (increased Rho 123 intracellular content). For that purpose, cells were pre-treated for $30 \mathrm{~min}$ with C27 $(10 \mu \mathrm{M})$, PCL@C27 NPs $(100 \mu \mathrm{g} / \mathrm{mL})$ or with elacridar $(10 \mu \mathrm{M})$, a well-known third-generation P-gp inhibitor, used as a positive control for this experiment. After that, $20 \mu \mathrm{M}$ RHO 123 was added and cells were incubated for $90 \mathrm{~min}$. The obtained results are presented in Figure 9.

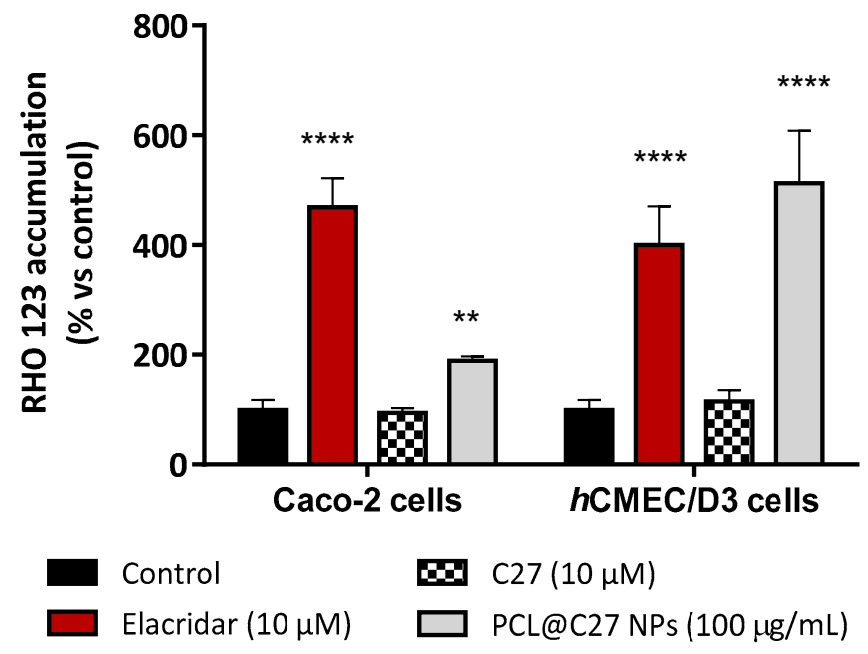

Figure 9. Accumulation of Rhodamine (RHO) 123 in Caco-2 and hCMEC/D3 cells. Data are expressed as percentage of fluorescence dye accumulation in control cells exposed only to RHO 123, arbitrarily set as $100 \%$, and are the means \pm SD of three independent assays. In all cases, $p$-values lower than 0.05 were considered significant ${ }^{* *} p<0.01$ and $\left.{ }^{* * *} p<0.0001\right)$.

As observed in Figure 9, no significant difference in RHO123 intracellular fluorescence was verified when C27 was tested, when compared to control cells. On the contrary, elacridar $(10 \mu \mathrm{M})$ acted as a P-gp inhibitor, avoiding the RHO 123 efflux from both cellular models, which resulted in a 5-fold increase in RHO123 intracellular fluorescence, when compared to control cells $(p<0.0001)$. The same behavior was obtained with PCL@C27 NPs. In this case, an increase of 1.9- and 5-fold of RHO 123 intracellular levels was found for the Caco-2 and $h$ CMEC/D3 cells, respectively. This data is in accordance with other works, which showed that NPs coated with Tween 80 have a good capacity to inhibit P-gp [76,77].

\section{Conclusions}

In this work, a potent, selective, and reversible IMAO-B was successfully encapsulated in PCL NPs coated with T80. The nanoprecipitation method was employed to obtain stable particles in physiological conditions with $D_{D L S}$ lower than $213 \mathrm{~nm}$ and a z-potential of around $-5 \mathrm{mV}$, with a high stability in physiological medium. The optimization process of $\mathrm{C} 27$ encapsulation gave rise to NPs with a final C27 concentration of $263.3 \pm 12.1 \mu \mathrm{M}, 400,000$-fold higher than its $\mathrm{IC}_{50}$ value $(670 \pm 130 \mathrm{pM})$. 
In physiological conditions, the nanoformulation sustainably released C27 over seven days, with a final release amount of $67.7 \pm 4.4 \%$. Furthermore, no cytotoxic effects of C27 and PCL@C27 NPs were observed in Caco-2 cells. In SH-SY5Y and $h$ CMEC/D3 cells, the encapsulation of C27 was essential to decrease its cytotoxicity in the conditions tested.

The uptake and permeability studies, performed with PCL@C6 NPs, showed that PEGylated PCL NPs were capable of accumulating in the cytoplasm of both neuronal and endothelial cells and surpassing the in vitro epithelial and endothelial cell monolayers. By extrapolation, one can infer that PCL@C27 NPs are able to deliver C27 across the intestine and BBB monolayer at concentrations higher than its $\mathrm{MAO}-\mathrm{B} \mathrm{IC}_{50}$ value.

Overall, our results provide evidence of the effectiveness of PCL nanocarriers to deliver neuroactive compounds that have bioavailability and physicochemical drawbacks. Further improvement and research, focused on in vivo long-term safety and efficacy studies, on polymeric nanomedicines will be, in the future, a promising tool to boost the success of clinical trials. Given the significant costs associated with drug discovery and development, it is becoming increasingly important to engineer targeted nanomaterial carriers allowing a sustained release of new neuroactive drug candidates.

Supplementary Materials: The following are available online at http://www.mdpi.com/1999-4923/11/7/331/s1. Table S1 is related to the EE\% and DLC\% values obtained for different formulations prepared with different amounts of feeding C27. Table S2 is related to $\mathrm{D}_{D L S}$ and z-potential values obtained in Milli-Q, PBS (1×, +/+), and HBSS media $(+/+)$. Figure S1 is related to the UV-Vis spectra of chromone C27.

Author Contributions: C.F., F.R. and F.B. conceived the overall study design; M.P. and F.C. prepared, purified and fully characterized the chromone C27; C.F. and M.P. produced and optimized the encapsulation of C27 in PCL NPs; M.P. measured the hydrodynamic size of NPs by DLS; J.G. performed the DSC studies; R.F.M. and F.A.A.P. performed the P-XRD characterization; C.F., E.M. and R.S. evaluated the cytotoxicity in SH-SY5Y and Caco-2 cells as well as the cellular uptake and P-gp inhibition in both Caco-2 and hCMEC/D3 cell lines; S.B. tested the cytotoxicity and permeability of NPs in hCMEC/D3 cells; S.B. conducted the quantification of coumarin C27; C.F. performed all rest of experiments presented in this manuscript; C.F. and F.B. wrote the draft manuscript; and all authors contributed to manuscript revision.

Funding: Pinto, M., Fernandes, C., Benfeito, S., Cagide, F. (NORTE-01-0145-FEDER-000028), Silva, R. (SFRH/BPD/110201/2015) and Mendes, R.F. (SFRH/BD/84231/2012) grants are supported by FCT, POPH and FEDER/COMPETE. The authors also thank the COST action CA15135 for support. This work was funded by FEDER funds through the Operational Programme Competitiveness Factors-FEDER/COMPETE-by national funds (FCT-Foundation for Science and Technology) and Norte Portugal Regional Operational Programme (Grants POCI-01-0145-FEDER-006980-UID/QUI/00081/2013, POCI-01-0145-FEDER-007679-UID/CTM/50011/2013, EXPL/CTM-NAN/0013/2013, POCI-01-0145-FEDER-029164 and NORTE-01-0145-FEDER-000028).

Conflicts of Interest: The authors declare no conflict of interest.

\section{References}

1. Taylor, J.P.; Hardy, J.; Fischbeck, K.H. Toxic Proteins in Neurodegenerative Disease. Science 2002, 296, 1991-1995. [CrossRef] [PubMed]

2. Mattson, M.P. Apoptosis in neurodegenerative disorders. Nat. Rev. Mol. Cell Biol. 2000, 1, 120. [CrossRef] [PubMed]

3. Fernández, M.; Barcia, E.; Fernández-Carballido, A.; Garcia, L.; Slowing, K.; Negro, S. Controlled release of rasagiline mesylate promotes neuroprotection in a rotenone-induced advanced model of Parkinson's disease. Int. J. Pharm. 2012, 438, 266-278. [CrossRef] [PubMed]

4. Massano, J.; Bhatia, K.P. Clinical Approach to Parkinson's disease: Features, Diagnosis, and Principles of Management. Cold Spring Harb. Perspect. Med. 2012, 2, a008870. [CrossRef] [PubMed]

5. Reis, J.; Cagide, F.; Chavarria, D.; Silva, T.; Fernandes, C.; Gaspar, A.; Uriarte, E.; Remião, F.; Alcaro, S.; Ortuso, F.; et al. Discovery of New Chemical Entities for Old Targets: Insights on the Lead Optimization of Chromone-Based Monoamine Oxidase B (MAO-B) Inhibitors. J. Med. Chem. 2016, 59, 5879-5893. [CrossRef] [PubMed]

6. Gaspar, A.; Matos, M.J.; Garrido, J.; Uriarte, E.; Borges, F. Chromone: A Valid Scaffold in Medicinal Chemistry. Chem. Rev. 2014, 114, 4960-4992. [CrossRef] [PubMed] 
7. Reis, J.; Gaspar, A.; Milhazes, N.; Borges, F. Chromone as a Privileged Scaffold in Drug Discovery: Recent Advances. J. Med. Chem. 2017, 60, 7941-7957. [CrossRef] [PubMed]

8. Fernandes, C.; Martins, C.; Fonseca, A.; Nunes, R.; Matos, M.J.; Silva, R.; Garrido, J.; Sarmento, B.; Remião, F.; Otero-Espinar, F.J.; et al. PEGylated PLGA Nanoparticles As a Smart Carrier to Increase the Cellular Uptake of a Coumarin-Based Monoamine Oxidase B Inhibitor. ACS Appl. Mater. Interfaces 2018, 10, 39557-39569. [CrossRef] [PubMed]

9. Molinspiration. Molinspiration Cheminformatics. Available online: http://www.molinspiration.com (accessed on 2 March 2017).

10. Singh, R.; Lillard, J.W. Nanoparticle-based targeted drug delivery. Exp. Mol. Pathol. 2009, 86, $215-223$. [CrossRef]

11. Ekladious, I.; Colson, Y.L.; Grinstaff, M.W. Polymer-drug conjugate therapeutics: Advances, insights and prospects. Nat. Rev. Drug Discov. 2018. [CrossRef]

12. Seju, U.; Kumar, A.; Sawant, K.K. Development and evaluation of olanzapine-loaded PLGA nanoparticles for nose-to-brain delivery: In vitro and in vivo studies. Acta Biomater. 2011, 7, 4169-4176. [CrossRef] [PubMed]

13. Mei, L.; Zhang, Y.; Zheng, Y.; Tian, G.; Song, C.; Yang, D.; Chen, H.; Sun, H.; Tian, Y.; Liu, K.; et al. A Novel Docetaxel-Loaded Poly ( $\varepsilon$-Caprolactone)/Pluronic F68 Nanoparticle Overcoming Multidrug Resistance for Breast Cancer Treatment. Nanoscale Res. Lett. 2009, 4, 1530-1539. [CrossRef] [PubMed]

14. Nance, E.A.; Woodworth, G.F.; Sailor, K.A.; Shih, T.-Y.; Xu, Q.; Swaminathan, G.; Xiang, D.; Eberhart, C.; Hanes, J. A Dense Poly (Ethylene Glycol) Coating Improves Penetration of Large Polymeric Nanoparticles Within Brain Tissue. Sci. Transl. Med. 2012, 4, 119-149. [CrossRef] [PubMed]

15. Calvo, P.; Gouritin, B.; Chacun, H.; Desmaële, D.; D’Angelo, J.; Noel, J.-P.; Georgin, D.; Fattal, E.; Andreux, J.P.; Couvreur, P. Long-Circulating PEGylated Polycyanoacrylate Nanoparticles as New Drug Carrier for Brain Delivery. Pharm. Res. 2001, 18, 1157-1166. [CrossRef] [PubMed]

16. Rizvi, S.A.A.; Saleh, A.M. Applications of nanoparticle systems in drug delivery technology. Saudi Pharm. J. 2018, 26, 64-70. [CrossRef] [PubMed]

17. Suk, J.S.; Xu, Q.; Kim, N.; Hanes, J.; Ensign, L.M. PEGylation as a strategy for improving nanoparticle-based drug and gene delivery. Adv. Drug Deliv. Rev. 2016, 99, 28-51. [CrossRef]

18. Wilson, B.; Samanta, M.K.; Santhi, K.; Kumar, K.P.S.; Paramakrishnan, N.; Suresh, B. Poly(n-butylcyanoacrylate) nanoparticles coated with polysorbate 80 for the targeted delivery of rivastigmine into the brain to treat Alzheimer's disease. Brain Res. 2008, 1200, 159-168. [CrossRef]

19. Wilson, B.; Samanta, M.K.; Santhi, K.; Kumar, K.P.S.; Paramakrishnan, N.; Suresh, B. Targeted delivery of tacrine into the brain with polysorbate 80-coated poly(n-butylcyanoacrylate) nanoparticles. Eur. J. Pharm. Biopharm. 2008, 70, 75-84. [CrossRef]

20. Ma, Y.; Zheng, Y.; Zeng, X.; Jiang, L.; Chen, H.; Liu, R.; Huang, L.; Mei, L. Novel docetaxel-loaded nanoparticles based on PCL-Tween 80 copolymer for cancer treatment. Int. J. Nanomed. 2011, 6, 2679-2688. [CrossRef]

21. Kurakhmaeva, K.B.; Djindjikhashvili, I.A.; Petrov, V.E.; Balabanyan, V.U.; Voronina, T.A.; Trofimov, S.S.; Kreuter, J.; Gelperina, S.; Begley, D.; Alyautdin, R.N. Brain targeting of nerve growth factor using poly(butyl cyanoacrylate) nanoparticles. J. Drug Target. 2009, 17, 564-574. [CrossRef]

22. Wang, Y.; Wang, C.; Gong, C.; Wang, Y.; Guo, G.; Luo, F.; Qian, Z. Polysorbate 80 coated poly ( $\varepsilon$-caprolactone)-poly (ethylene glycol)-poly ( $\varepsilon$-caprolactone) micelles for paclitaxel delivery. Int. J. Pharm. 2012, 434, 1-8. [CrossRef] [PubMed]

23. Saraiva, C.; Praça, C.; Ferreira, R.; Santos, T.; Ferreira, L.; Bernardino, L. Nanoparticle-mediated brain drug delivery: Overcoming blood-brain barrier to treat neurodegenerative diseases. J. Control. Release 2016, 235, 34-47. [CrossRef] [PubMed]

24. Le Droumaguet, B.; Souguir, H.; Brambilla, D.; Verpillot, R.; Nicolas, J.; Taverna, M.; Couvreur, P.; Andrieux, K. Selegiline-functionalized, PEGylated poly(alkyl cyanoacrylate) nanoparticles: Investigation of interaction with amyloid- $\beta$ peptide and surface reorganization. Int. J. Pharm. 2011, 416, 453-460. [CrossRef] [PubMed]

25. Gomes, M.J.; Fernandes, C.; Martins, S.; Borges, F.; Sarmento, B. Tailoring Lipid and Polymeric Nanoparticles as siRNA Carriers towards the Blood-Brain Barrier-From Targeting to Safe Administration. J. Neuroimmune Pharmacol. 2017, 12, 107-119. [CrossRef] [PubMed] 
26. Gou, P.-F.; Zhu, W.-P.; Shen, Z.-Q. Synthesis, Self-Assembly, and Drug-Loading Capacity of Well-Defined Cyclodextrin-Centered Drug-Conjugated Amphiphilic A14B7 Miktoarm Star Copolymers Based on Poly(E-caprolactone) and Poly(ethylene glycol). Biomacromolecules 2010, 11, 934-943. [CrossRef] [PubMed]

27. Gu, C.; Huang, N.; Xu, F.; Gao, J.; Jiang, D. Cascade exciton-pumping engines with manipulated speed and efficiency in light-harvesting porous $\pi$-network films. Sci. Rep. 2015, 5, 8867. Available online: https: //www.nature.com/articles/srep08867\#supplementary-information (accessed on 11 July 2019). [CrossRef] [PubMed]

28. Teixeira, J.; Oliveira, C.; Amorim, R.; Cagide, F.; Garrido, J.; Ribeiro, J.A.; Pereira, C.M.; Silva, A.F.; Andrade, P.B.; Oliveira, P.J.; et al. Development of hydroxybenzoic-based platforms as a solution to deliver dietary antioxidants to mitochondria. Sci. Rep. 2017, 7, 6842. [CrossRef]

29. Santillo, M.F.; Liu, Y.; Ferguson, M.; Vohra, S.N.; Wiesenfeld, P.L. Inhibition of monoamine oxidase (MAO) by $\beta$-carbolines and their interactions in live neuronal (PC12) and liver (HuH-7 and MH1C1) cells. Toxicol. In Vitro 2014, 28, 403-410. [CrossRef]

30. Van Breemen, R.B.; Li, Y. Caco-2 cell permeability assays to measure drug absorption. Expert Opin. Drug Metab. Toxicol. 2005, 1, 175-185. [CrossRef]

31. Jouan, E.; Le Vée, M.; Mayati, A.; Denizot, C.; Parmentier, Y.; Fardel, O. Evaluation of P-Glycoprotein Inhibitory Potential Using a Rhodamine 123 Accumulation Assay. Pharmaceutics 2016, 8, 12. [CrossRef]

32. Gao, X.; Wang, B.; Wei, X.; Rao, W.; Ai, F.; Zhao, F.; Men, K.; Yang, B.; Liu, X.; Huang, M.; et al. Preparation, characterization and application of star-shaped PCL/PEG micelles for the delivery of doxorubicin in the treatment of colon cancer. Int. J. Nanomed. 2013, 8, 971-982. [CrossRef] [PubMed]

33. Bensaid, F.; du Boullay, O.T.; Amgoune, A.; Pradel, C.; Reddy, L.H.; Didier, E.; Sable, S.; Louit, G.; Bazile, D.; Bourissou, D. Y-Shaped mPEG-PLA Cabazitaxel Conjugates: Well-Controlled Synthesis by Organocatalytic Approach and Self-Assembly into Interface Drug-Loaded Core-Corona Nanoparticles. Biomacromolecules 2013, 14, 1189-1198. [CrossRef] [PubMed]

34. Gamisans, F.; Lacoulonche, F.; Chauvet, A.; Espina, M.; Garcia, M.L.; Egea, M.A. Flurbiprofen-loaded nanospheres: Analysis of the matrix structure by thermal methods. Int. J. Pharm. 1999, 179, 37-48. [CrossRef]

35. Calvo, P.; Vila-Jato, J.L.; Alonso, M.J. Comparative in vitro evaluation of several colloidal systems, nanoparticles, nanocapsules, and nanoemulsions, as ocular drug carriers. J. Pharm. Sci. 1996, 85, 530-536. [CrossRef] [PubMed]

36. Guo, F.; Wu, F.; Mu, Y.; Hu, Y.; Zhao, X.; Meng, W.; Giesy, J.P.; Lin, Y. Characterization of organic matter of plants from lakes by thermal analysis in a N2 atmosphere. Sci. Rep. 2016, 6, 22877. [CrossRef] [PubMed]

37. Zhang, Y.; Tang, L.; Sun, L.; Bao, J.; Song, C.; Huang, L.; Liu, K.; Tian, Y.; Tian, G.; Li, Z.; et al. A novel paclitaxel-loaded poly ( $\varepsilon$-caprolactone)/Poloxamer 188 blend nanoparticle overcoming multidrug resistance for cancer treatment. Acta Biomater. 2010, 6, 2045-2052. [CrossRef] [PubMed]

38. Sanchez-Lopez, E.; Egea, M.A.; Cano, A.; Espina, M.; Calpena, A.C.; Ettcheto, M.; Camins, A.; Souto, E.B.; Silva, A.M.; Garcia, M.L. PEGylated PLGA nanospheres optimized by design of experiments for ocular administration of dexibuprofen-in vitro, ex vivo and in vivo characterization. Colloids Surf. B Biointerfaces 2016, 145, 241-250. [CrossRef]

39. Panyam, J.; Williams, D.; Dash, A.; Leslie-Pelecky, D.; Labhasetwar, V. Solid-state solubility influences encapsulation and release of hydrophobic drugs from PLGA/PLA nanoparticles. J. Pharm. Sci. 2004, 93, 1804-1814. [CrossRef]

40. Hombreiro Pérez, M.; Zinutti, C.; Lamprecht, A.; Ubrich, N.; Astier, A.; Hoffman, M.; Bodmeier, R.; Maincent, P. The preparation and evaluation of poly ( $\epsilon$-caprolactone) microparticles containing both a lipophilic and a hydrophilic drug. J. Control. Release 2000, 65, 429-438. [CrossRef]

41. Silveira, N.; Longuinho, M.M.; Leitão, S.G.; Silva, R.S.; Lourenço, M.C.; Silva, P.E.; Maria do Carmo, F.R.; Abraçado, L.G.; Finotelli, P.V. Synthesis and characterization of the antitubercular phenazine lapazine and development of PLGA and PCL nanoparticles for its entrapment. Mater. Sci. Eng. C 2016, 58, 458-466. [CrossRef]

42. Deshmukh, R.K.; Naik, J.B. Aceclofenac microspheres: Quality by design approach. Mater. Sci. Eng. C 2014, 36, 320-328. [CrossRef] [PubMed]

43. Pinkerton, N.M.; Grandeury, A.; Fisch, A.; Brozio, J.; Riebesehl, B.U.; Prud'homme, R.K. Formation of Stable Nanocarriers by in Situ Ion Pairing during Block-Copolymer-Directed Rapid Precipitation. Mol. Pharm. 2013, 10, 319-328. [CrossRef] [PubMed] 
44. Li, J.W.; Zhang, C.; Li, J.; Fan, L.; Jiang, X.G.; Chen, J.; Pang, Z.Q.; Zhang, Q.Z. Brain Delivery of NAP with PEG-PLGA Nanoparticles Modified with Phage Display Peptides. Pharm. Res. 2013, 30, 1813-1823. [CrossRef] [PubMed]

45. Shilo, M.; Motiei, M.; Hana, P.; Popovtzer, R. Transport of nanoparticles through the blood-brain barrier for imaging and therapeutic applications. Nanoscale 2014, 6, 2146-2152. [CrossRef] [PubMed]

46. Massella, D.; Celasco, E.; Salaün, F.; Ferri, A.; Barresi, A. Overcoming the Limits of Flash Nanoprecipitation: Effective Loading of Hydrophilic Drug into Polymeric Nanoparticles with Controlled Structure. Polymers 2018, 10, 1092. [CrossRef] [PubMed]

47. Fornaguera, C.; Dols-Perez, A.; Calderó, G.; García-Celma, M.J.; Camarasa, J.; Solans, C. PLGA nanoparticles prepared by nano-emulsion templating using low-energy methods as efficient nanocarriers for drug delivery across the blood-brain barrier. J. Control. Release 2015, 211, 134-143. [CrossRef] [PubMed]

48. Pfeiffer, C.; Rehbock, C.; Hühn, D.; Carrillo-Carrion, C.; de Aberasturi, D.J.; Merk, V.; Barcikowski, S.; Parak, W.J. Interaction of colloidal nanoparticles with their local environment: The (ionic) nanoenvironment around nanoparticles is different from bulk and determines the physico-chemical properties of the nanoparticles. J. R. Soc. Interface 2014, 11. [CrossRef] [PubMed]

49. Sanna, V.; Siddiqui, I.A.; Sechi, M.; Mukhtar, H. Resveratrol-Loaded Nanoparticles Based on Poly(epsilon-caprolactone) and Poly(D,L-lactic-co-glycolic acid)-Poly(ethylene glycol) Blend for Prostate Cancer Treatment. Mol. Pharm. 2013, 10, 3871-3881. [CrossRef] [PubMed]

50. Kamaly, N.; Yameen, B.; Wu, J.; Farokhzad, O.C. Degradable Controlled-Release Polymers and Polymeric Nanoparticles: Mechanisms of Controlling Drug Release. Chem. Rev. 2016, 116, 2602-2663. [CrossRef] [PubMed]

51. Sriamornsak, P.; Thirawong, N.; Weerapol, Y.; Nunthanid, J.; Sungthongjeen, S. Swelling and erosion of pectin matrix tablets and their impact on drug release behavior. Eur. J. Pharm. Biopharm. 2007, 67, 211-219. [CrossRef]

52. Riederer, P.; Laux, G. MAO-inhibitors in Parkinson's disease. Exp. Neurobiol. 2011, 20, 1-17. [CrossRef] [PubMed]

53. Schneider, L.; Giordano, S.; Zelickson, B.R.; Johnson, M.; Benavides, G.; Ouyang, X.; Fineberg, N.; Darley-Usmar, V.M.; Zhang, J. Differentiation of SH-SY5Y cells to a neuronal phenotype changes cellular bioenergetics and the response to oxidative stress. Free Radic. Biol. Med. 2011, 51, 2007-2017. [CrossRef] [PubMed]

54. Lopes, F.M.; Schröder, R.; da Frota Júnior, M.L.C.; Zanotto-Filho, A.; Müller, C.B.; Pires, A.S.; Meurer, R.T.; Colpo, G.D.; Gelain, D.P.; Kapczinski, F.; et al. Comparison between proliferative and neuron-like SH-SY5Y cells as an in vitro model for Parkinson disease studies. Brain Res. 2010, 1337, 85-94. [CrossRef] [PubMed]

55. Je,H.J.; Kim, E.S.; Lee, J.-S.; Lee, H.G. Release Properties and Cellular Uptake in Caco-2 Cells of Size-Controlled Chitosan Nanoparticles. J. Agric. Food Chem. 2017, 65, 10899-10906. [CrossRef] [PubMed]

56. Lu, H.; Chen, J.; Huang, H.; Zhou, M.; Zhu, Q.; Yao, S.Q.; Chai, Z.; Hu, Y. Iron modulates the activity of monoamine oxidase B in SH-SY5Y cells. BioMetals 2017, 30, 599-607. [CrossRef] [PubMed]

57. Shawahna, R.; Uchida, Y.; Declèves, X.; Ohtsuki, S.; Yousif, S.; Dauchy, S.; Jacob, A.; Chassoux, F.; Daumas-Duport, C.; Couraud, P.-O.; et al. Transcriptomic and Quantitative Proteomic Analysis of Transporters and Drug Metabolizing Enzymes in Freshly Isolated Human Brain Microvessels. Mol. Pharm. 2011, 8, 1332-1341. [CrossRef] [PubMed]

58. Geldenhuys, W.; Mbimba, T.; Bui, T.; Harrison, K.; Sutariya, V. Brain-targeted delivery of paclitaxel using glutathione-coated nanoparticles for brain cancers. J. Drug Target. 2011, 19, 837-845. [CrossRef]

59. Stanimirovic, D.B.; Bani-Yaghoub, M.; Perkins, M.; Haqqani, A.S. Blood-brain barrier models: In vitro to in vivo translation in preclinical development of CNS-targeting biotherapeutics. Expert Opin. Drug Discov. 2015, 10, 141-155. [CrossRef]

60. Veszelka, S.; Tóth, A.; Walter, F.R.; Tóth, A.E.; Gróf, I.; Mészáros, M.; Bocsik, A.; Hellinger, É.; Vastag, M.; Rákhely, G.; et al. Comparison of a Rat Primary Cell-Based Blood-Brain Barrier Model with Epithelial and Brain Endothelial Cell Lines: Gene Expression and Drug Transport. Front. Mol. Neurosci. 2018, 11, 166. [CrossRef]

61. Artursson, P.; Palm, K.; Luthman, K. Caco-2 monolayers in experimental and theoretical predictions of drug transport1PII of original article: S0169-409X(96)00415-2. The article was originally published in Advanced Drug Delivery Reviews 22 (1996) 67-84.1. Adv. Drug Deliv. Rev. 2001, 46, 27-43. [CrossRef] 
62. Weksler, B.; Romero, I.A.; Couraud, P.-O. The hCMEC/D3 cell line as a model of the human blood brain barrier. Fluids Barriers CNS 2013, 10, 16. [CrossRef] [PubMed]

63. Fernandes, C.; Pinto, M.; Martins, C.; Gomes, M.J.; Sarmento, B.; Oliveira, P.J.; Remião, F.; Borges, F. Development of a PEGylated-Based Platform for Efficient Delivery of Dietary Antioxidants Across the Blood-Brain Barrier. Bioconj. Chem. 2018, 29, 1677-1689. [CrossRef] [PubMed]

64. Sugano, K.; Kansy, M.; Artursson, P.; Avdeef, A.; Bendels, S.; Di, L.; Ecker, G.F.; Faller, B.; Fischer, H.; Gerebtzoff, G.; et al. Coexistence of passive and carrier-mediated processes in drug transport. Nat. Rev. Drug Discov. 2010, 9, 597-614. [CrossRef] [PubMed]

65. Win, K.Y.; Feng, S.S. Effects of particle size and surface coating on cellular uptake of polymeric nanoparticles for oral delivery of anticancer drugs. Biomaterials 2005, 26, 2713-2722. [CrossRef] [PubMed]

66. Murugan, K.; Choonara, Y.E.; Kumar, P.; Bijukumar, D.; du Toit, L.C.; Pillay, V. Parameters and characteristics governing cellular internalization and trans-barrier trafficking of nanostructures. Int. J. Nanomed. 2015, 10, 2191-2206. [CrossRef]

67. Deli, M.A. Potential use of tight junction modulators to reversibly open membranous barriers and improve drug delivery. Biochim. Biophys. Acta Biomembr. 2009, 1788, 892-910. [CrossRef] [PubMed]

68. Bhavna Md, S.; Ali, M.; Baboota, S.; Sahni, J.K.; Bhatnagar, A.; Ali, J. Preparation, characterization, in vivo biodistribution and pharmacokinetic studies of donepezil-loaded PLGA nanoparticles for brain targeting. Drug Dev. Ind. Pharm. 2014, 40, 278-287. [CrossRef]

69. Zhu, Q.; Song, W.; Xia, D.; Fan, W.; Yu, M.; Guo, S.; Zhu, C.; Gan, Y. A poly-1-glutamic acid functionalized nanocomplex for improved oral drug absorption. J. Mater. Chem. B 2015, 3, 8508-8517. [CrossRef]

70. Poller, B.; Gutmann, H.; Krähenbühl, S.; Weksler, B.; Romero, I.; Couraud, P.-O.; Tuffin, G.; Drewe, J.; Huwyler, J. The human brain endothelial cell line hCMEC/D3 as a human blood-brain barrier model for drug transport studies. J. Neurochem. 2008, 107, 1358-1368. [CrossRef]

71. Amin, M.L. P-glycoprotein Inhibition for Optimal Drug Delivery. Drug Target Insights 2013, 7, $27-34$. [CrossRef]

72. Werle, M. Natural and Synthetic Polymers as Inhibitors of Drug Efflux Pumps. Pharm. Res. 2008, 25, 500-511. [CrossRef] [PubMed]

73. Shen, Q.; Lin, Y.; Handa, T.; Doi, M.; Sugie, M.; Wakayama, K.; Okada, N.; Fujita, T.; Yamamoto, A. Modulation of intestinal P-glycoprotein function by polyethylene glycols and their derivatives by in vitro transport and in situ absorption studies. Int. J. Pharm. 2006, 313, 49-56. [CrossRef] [PubMed]

74. Friche, E.; Jensen, P.; Sehested, M.; Demant, E.J.; Nissen, N.N. The solvents Cremophor EL and Tween 80 modulate daunorubicin resistance in the multidrug resistant Ehrlich ascites tumor. Cancer Commun. 1990, 2 , 297-303. [PubMed]

75. Hugger, E.D.; Audus, K.L.; Borchardt, R.T. Effects of Poly(ethylene glycol) on Efflux Transporter Activity in Caco-2 Cell Monolayers. J. Pharm. Sci. 2002, 91, 1980-1990. [CrossRef] [PubMed]

76. Netsomboon, K.; Laffleur, F.; Suchaoin, W.; Bernkop-Schnürch, A. Novel in vitro transport method for screening the reversibility of P-glycoprotein inhibitors. Eur. J. Pharm. Biopharm. 2016, 100, 9-14. [CrossRef] [PubMed]

77. Tian, X.-H.; Lin, X.-N.; Wei, F.; Feng, W.; Huang, Z.-C.; Wang, P.; Ren, L.; Diao, Y. Enhanced brain targeting of temozolomide in polysorbate- 80 coated polybutylcyanoacrylate nanoparticles. Int. J. Nanomed. 2011, 6, 445-452. [CrossRef]

(C) 2019 by the authors. Licensee MDPI, Basel, Switzerland. This article is an open access article distributed under the terms and conditions of the Creative Commons Attribution (CC BY) license (http://creativecommons.org/licenses/by/4.0/). 